Florida State University College of Law

Scholarship Repository

Scholarly Publications

Spring 2014

\title{
Capital Rigidities, Latent Externalities
}

Shi-Ling Hsu

Florida State University College of Law

Follow this and additional works at: https://ir.law.fsu.edu/articles

Part of the Energy and Utilities Law Commons, Environmental Law Commons, and the Law and Society Commons

\section{Recommended Citation}

Shi-Ling Hsu, Capital Rigidities, Latent Externalities, 51 Hous. L. REV. 719 (2014),

Available at: https://ir.law.fsu.edu/articles/493

This Article is brought to you for free and open access by Scholarship Repository. It has been accepted for inclusion in Scholarly Publications by an authorized administrator of Scholarship Repository. For more information, please contact efarrell@law.fsu.edu. 


\title{
ARTICLE
}

\section{CAPITAL RIGIDITIES, LATENT EXTERNALITIES}

\author{
Shi-Ling Hsu*
}

\begin{abstract}
Capital, one of two fundamental inputs to production, is critical to economic growth. As such, legal rules and institutions generally seek to create more of it, and they also seek to protect existing capital from policy changes. However, capital is often durable, and during its natural life, information may emerge pointing to negative externalities resulting from operation of that capital. Legal rules and institutions, in seeking to stimulate and sustain economic growth by promoting and protecting capital, thus tend to induce the creation of excess capital. This abundance of capital creates excess resistance to new regulation or policy reform, as capital owners will have a larger capital stake to defend and will expend more resources to resist changes in their legal and economic environment.

This theory of capital has special application to environmental externalities, which are commonly latent. Capital is thus almost always obtained with incomplete information about potential environmental externalities. Environmental law is the means by which many previously unforeseen externalities are sought to be addressed, but any change in environmental law

* Larson Professor of Law, Florida State University College of Law. The Author gratefully acknowledges the comments of Steve Johnson, Emily Hammond, David Dana, Michael Barsa, and Alexandra Klass, and the excellent research assistance of Patrick Walker and Sarah McCalla, and of the outstanding library staff at the Florida State University College of Law. This Article benefitted greatly from comments from attendees at the Fourth Annual Meeting of the Society for Environmental Law and Economics, the 2012 Annual Meeting of the International Society for New Institutional Economics, and the Environmental Colloquium workshop at the Northwestern University School of Law. This work has been supported by funding from Carbon Management Canada.
\end{abstract}


is invariably challenged by capital owners. By enacting legal rules to promote and protect capital, developed societies have unwittingly erected larger barriers to environmental reform. Over time, environmental law has become more difficult to reform and the source of more litigation.

\section{TABLE OF CONTENTS}

I. INTRODUCTION .............................................................. 720

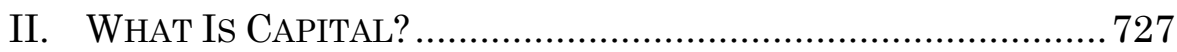

III. How CAPITAL IMPEDES REFORM.......................................735

A. Overcapitalization as a Drag on Environmental

Reform ................................................................. 736

B. A Model of How Capital Impedes Reform ................... 739

IV. The Role of LaW AND LaWmaking In PRomoting AND

PROTECTING CAPITAL ............................................................ 743

A. Tax Benefits for Energy Industries ........................... 744

B. Tax Benefits for Mining Industries............................753

C. Electric Utility Regulation ....................................... 755

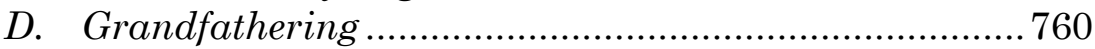

E. Regulatory Takings Jurisprudence ............................764

F. The Politics of Human and Social Capital................... 768

V. Whither, Capital? A Refocus on Public Goods............ 772

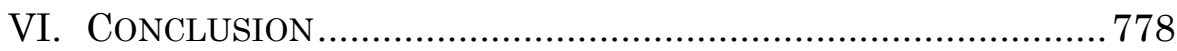

\section{INTRODUCTION}

Capital is good. Capital and labor are the two stylized inputs to production. ${ }^{1}$ Among economists, capital is universally regarded

1. The Cobb-Douglas production function, which every economics student learns about in undergraduate economics, posits production as a function of the quantity and productivity of just two types of inputs: labor and capital. See generally Gerald Beer, The Cobb-Douglas Production Function, 53 Mathematics Mag. 44, 4445 (1980) (describing how the function is commonly featured in economics and even calculus texts); Charles W. Cobb \& Paul H. Douglas, A Theory of Production, 18 AM. ECON. Rev. (PAPERS \& Proc.) 151-59 (Supp. 1928) (deriving and discussing the formula); Paul H. Douglas, The Cobb-Douglas Production Function Once Again: Its History, Its Testing, and Some New Empirical Values, 84 J. PoL. ECON. 903, 903-04 (1976) (discussing the inputs of labor and capital within the Cobb-Douglas formula). The now-familiar Cobb-Douglas formulation, $Y=A L^{a} K^{\beta}$, with $Y$ representing output, $L$ representing labor, and $K$ representing capital, is a foundational relation in 
as positively related to economic growth. ${ }^{2}$ If one asks (as numerous economists have asked) the complicated question of why some countries are so much richer and produce so much more than others, ${ }^{3}$ one can easily rule out the availability of labor as a limiting input because most developing countries are awash in cheap labor. ${ }^{4}$ What is left? Capital. ${ }^{5}$ Furthermore, more capital is always better. Additional capital may or may not be worth its cost, but it never decreases productivity. ${ }^{6}$

Capital is good, except when it isn't. After capital is acquired, new information may emerge suggesting that the

economic theory. Beer, supra, at 44-45 (describing how output can be modeled by this well-regarded function).

2. Robert Solow's fundamental neoclassical growth model posits growth as a general function of labor, capital, and technology, the latter being a multiplier that makes the other two inputs more productive. Robert M. Solow, A Contribution to the Theory of Economic Growth, 70 Q.J. ECON. 65, 66, 85 (1956); see also W. KIP VISCUSI, JosEPH E. HARRINGTON, JR. \& JOHN M. VERNON, ECONOMICS OF REGULATION AND ANTITRUST 93 (4th ed. 2005) (emphasizing Solow's conclusion regarding the relative importance of technology to output); George N. Hatsopoulos, Paul R. Krugman \& Lawrence H. Summers, U.S. Competitiveness: Beyond the Trade Deficit, 241 SCIENCE 299, 299, 301-02 (1988) (arguing for a broader definition of capital to explain relative American lagging in productivity growth); N. Gregory Mankiw, The Growth of Nations, BROOKINGS PAPERS ON ECON. ACTIVITY, no. 1, 1995, at 275, 292, 308 (explaining the positive externalities to capital).

3. See, e.g., Douglas A. Hibbs, Jr. \& Ola Olsson, Geography, Biogeography, and Why Some Countries Are Rich and Others Are Poor, 101 PROC. NAT'L ACAD. SCI. 3715, 3715 (2004) ("The prosperity of nations varies enormously.... How can this large variation in the wealth of nations be explained?"); Mathias Risse, What We Owe to the Global Poor, 9 J. ETHICS 81, 83 (2005) (tracing the question back to Adam Smith's Wealth of Nations).

4. See, e.g., Michael P. Todaro, A Model of Labor Migration and Urban Unemployment in Less Developed Countries, 59 AM. ECON. REv. 138, 138-39 (1969) ("[E]ven the most casual observer of these countries cannot help but be overwhelmed by the proportion of the urban labor force which is apparently untouched by the so-called 'modern' economy.”); Adrian Wood, Openness and Wage Inequality in Developing Countries: The Latin American Challenge to East Asian Conventional Wisdom, 11 WoRLD BANK ECON. REV. 33, 34 (1997) ("The belief that increased openness reduces wage inequality in developing countries rests on an apparently indisputable fact-that the supply of unskilled labor, relative to the supply of skilled labor, is larger in developing than in developed countries ....").

5. Also, technology, which in the Cobb-Douglas and Solow formulations acts as a multiplier for labor productivity and capital productivity, is not considered an input for productivity. See, e.g., Paul Krugman, A Model of Innovation, Technology Transfer, and the World Distribution of Income, 87 J. POL. ECON. 253, 254-55, 259 (1979) (developing a model with labor as the only factor of production, while including technical progress only in the form of the availability of new products, rather than an increased volume of production of old products); Richard R. Nelson \& Edmund S. Phelps, Investment in Humans, Technological Diffusion, and Economic Growth, 56 AM. ECON. REV. (PAPERS \& PROC.) 69, 71 (1966) ("[T]echnical progress is Harrod-neutral everywhere (i.e., for all capital-labor ratios), so that progress can be described as purely labor-augmenting.").

6. Idiosyncratic exceptions may exist, but the Cobb-Douglas production function is almost never deployed with capital having an inverse relationship with productivity. See Beer, supra note 1, at 45 (describing the function as concave such that as long as there is input, output will increase, even if at a decreasing rate). 
capital might not be so useful after all. ${ }^{7}$ The new information may reveal some harmful effects of operating that capital or indicate that continued employment of that capital produces net social harms. Or, the new information may suggest that capital is outdated, and that other forms of capital or other technologies would be more efficient and produce greater net social benefits. In short, new information can render existing capital obsolete in a number of different ways, most notably by revealing the presence of latent negative externalities. ${ }^{8}$ But even obsolete capital can be extremely difficult to dislodge. ${ }^{9}$ Unless obsolete capital can be profitably redeployed, attempts to regulate or internalize externalities ${ }^{10}$ resulting from the operation of capital will be vigorously opposed by its owners. ${ }^{11}$

This theory of capital has special application to environmental externalities, which are by their nature commonly latent. The most serious environmental problems are no longer obvious and visceral. ${ }^{12}$ Leaky industrial drums sitting atop

7. Shi-Ling Hsu, The Case for a Carbon Tax: Getting Past Our Hang-Ups to Effective Climate Policy 41, 43 (2011) ("[T] he problem with mandating an expensive environmental technology is the economic irreversibility of capital expenditures."); Clayton Christensen, Thomas Craig \& Stuart Hart, The Great Disruption, ForeIGN AFF., Mar./Apr. 2001, at 80, 81-82 (describing disruptive technologies- "cheaper, simpler, and more convenient products or services"-and the challenges these technologies pose for companies).

8. See Christensen, Craig \& Hart, supra note 7, at 81-85 (discussing the effect of "disruptive technologies"-a form of new information-on existing industries, noting that these technologies "have plunged many of history's best companies into crisis and, ultimately, failure").

9. See id. at 88-89 (contrasting the American economy's success at repeating the cycle of starting new companies that create disruptive growth disruption against the Japanese economy's failure to develop a venture-capital infrastructure); infra Part III.B (explaining how the redeployment of capital is difficult due, in part, to switching costs).

10. An externality is a general term for an effect of a decision, on a party other than the decision-maker, that the decision-maker does not take into account. For a discussion, see Carl J. Dahlman, The Problem of Externality, 22 J.L. \& ECON. 141, 147 (1979), which discusses the transaction costs of externalities. "The conventional view of externalities, whether associated with socially undesirable or desirable activities, is that externalities arise as the unintended byproduct of otherwise self-serving activities." Daniel B. Kelly, Strategic Spillovers, 111 CoLUM. L. REV. 1641, 1649-51 (2011).

11. See C. Edwin Baker, An Economic Critique of Free Trade in Media Products, 78 N.C. L. REV. 1357, 1418-19 (2000) ("For the firm, even if externalities reflect real preferences that people theoretically are willing to pay to satisfy, as long as they are externalities ... these preferences are not brought to bear on the firm's decisions, usually because of transaction costs or collective action problems. Externalities are irrelevant because they fall into neither the firm's expense nor revenue column."); infra Part III.B (examining how overcapitalization creates resistance to policy reform).

12. See, e.g., JACK C. Bender, The Duty to Disclose Latent Environmental HAZARdS IN Mineral Property TRANSACTIONS §2.01 (1994), available at http://www.emlf.org/clientuploads/directory/whitepaper/Bender_94.pdf (noting that many environmental externalities of mineral extraction activities are "hidden and would not be discovered or anticipated through visual inspection of the property"); Environmental 
playgrounds are no longer the symbol of environmental blight. The focus of environmental law has turned towards less visible problems, such as the emission of carbon dioxide causing global climate change, ${ }^{13}$ and the emission of fine particulate matterless than 2.5 microns in diameter-quietly causing millions of premature deaths annually. ${ }^{14}$ But these kinds of environmental problems only become apparent after decades of careful and credible research. ${ }^{15}$ In the meantime, billions of dollars of capital may accumulate without any serious attempt to consider the possibility of latent externalities.

Reform or new legislation leading to resolution of modern environmental problems has thus been elusive well before Congress reached its current state of gridlock. ${ }^{16}$ Congress has not passed a new federal environmental statute since $1990^{17}$ despite

Effects of Acid Rain, EPA, http://www.epa.gov/region1/eco/acidrain/enveffects.html (last updated Sept. 19, 2013) (discussing some of the more "subtle" effects of acid rain).

13. For a relatively brief treatment of this extremely broad, complex, and literatureheavy problem, see generally Robert Henson, The Rough Guide to Climate Change (1st ed. 2006).

14. An extremely sophisticated body of epidemiological research has emerged over decades of careful research linking concentrations of fine particulate matter with premature mortalities. See, e.g., Francine Laden et al., Reduction in Fine Particulate Air Pollution and Mortality: Extended Follow-up of the Harvard Six Cities Study, 173 AM. J. RESPIRATORY \& CRITICAL CARE MED. 667, 667-69 \& tbl.1 (2006) (finding an increase in overall mortality associated with each $10-\mu \mathrm{g} / \mathrm{m}^{3}$ increase in fine particulate matter pollution); Johanna Lepeule et al., Chronic Exposure to Fine Particles and Mortality: An Extended Follow-up of the Harvard Six Cities Study from 1974 to 2009, 120 ENVTL. HEALTh PERSP. 965, 968 (2012) (finding evidence that exposure to fine particulate matter can lead to early mortality); C. Arden Pope III et al., Lung Cancer, Cardiopulmonary Mortality, and Long-term Exposure to Fine Particulate Air Pollution, 287 JAMA 1132, $1136 \&$ tbl.2 (2002) (finding that exposure to fine particulate matter is associated with allcause, cardiopulmonary, and lung cancer mortality). Recent studies have estimated that fine particulate matter pollution causes over two million premature deaths annually, Raquel A. Silva et al., Global Premature Mortality Due to Anthropogenic Outdoor Air Pollution and the Contribution of Past Climate Change, EnVTL. Res. LeTTERs, July-Sept. 2013, at 1, 4, and 1.2 million deaths in China alone, Edward Wong, Early Deaths Linked to China's Air Pollution Totaled 1.2 Million in 2010, Data Shows, N.Y. Times, Apr. 2, 2013, at A9.

15. See, e.g., Lepeule et al., supra note 14, at 965, 968 (describing how research regarding the health impact of fine particulate matter utilized data gathered by Harvard from 1974 to 1977 and 1979 to 2009).

16. Jonathan H. Adler, Conservative Principles for Environmental Reform, 23 DUKE ENVTL. L. \& POL'Y F. 253, 253 (2013) (arguing that major reform is necessary because only minor bills have passed since the Clean Air Act in 1990).

17. This Author considers the last significant federal environmental legislation passed by Congress to be the Clean Air Act Amendments of 1990, Pub. L. No. 101-549, 104 Stat. 2399 (codified as amended at 42 U.S.C. $\$ \S 7401-7671 q$ (2006)). See also Barton H. Thompson, Jr., A Federal Act to Promote Integrated Water Management: Is the CZMA a Useful Model?, 42 ENVTL. L. 201, 203 \& n.10 (2012) ("Congress has passed neither major new environmental legislation nor significant water reform measures for almost two decades.”). 
the existence of a number of under-regulated industries. ${ }^{18}$ Prevailing explanations for this inertia in these areas of law fall broadly into three categories: (i) public choice explanations; ${ }^{19}$ (ii) framing problems; ${ }^{20}$ and (iii) doubts about the importance of the underlying problem. ${ }^{21}$ While all of these explanations have

18. Nicholas Z. Muller, Robert Mendelsohn \& William Nordhaus, Environmental Accounting for Pollution in the United States Economy, 101 AM. EcON. REV. 1649, 1665 (2011) (highlighting seven industries which are not efficiently regulated). Whether certain industries and industrial practices are truly more harmful than productive is of course a challenging question to answer, but an important recent analysis suggests good reason to suspect there are many such industries. Id. at 1664-65. Using integrated assessment models, which model environmental and economic impacts together, Muller, Mendelsohn, and Nordhaus created an analysis of the net gross external damages of all point-source polluters of all pollutants in the United States and found that their best estimates of gross external damages of seven industries exceed their contribution to economic activity. Id. at 1659, 1664-65. Those industries are solid waste combustion, stone mining and quarrying, sewage treatment, oil- and coal-fired power generation, marinas, and petroleum and coal products. $I d$. at 1665 . Given the somewhat restrictive assumptions in this study about, for example, nonmarket damages to ecological systems, one suspects that there are many more than seven industries that are more harmful than valuable. $I d$. at $1654,1667,1672-73$.

19. For example, one common public choice explanation is that intensely affected regulated industries are more motivated to resist reform than lightly affected and widely dispersed majorities are to advance reform. See Gebhard Kirchgässner \& Friedrich Schneider, On the Political Economy of Environmental Policy, 115 PuB. Choice 369, 373, 377 (2003) (describing how industries burdened by environmental regulations are opposed to the use of economic instruments). If that is the case, then one might expect the politics of policy change to favor inertia. See James M. Buchanan \& Gordon Tullock, The Calculus of Consent: Logical Foundations of Constitutional Democracy 18, $21-$ 22, 29 (1962) (assuming actors will "choose 'more' rather than 'less' when confronted with the opportunity for choice in a political process," when "more" advances their economic position); see also George J. Stigler, The Theory of Economic Regulation, 2 BELL J. ECON. \& MGMT. SCI. 3, 12 (1971) (discussing the high costs of legislative reform and stating that "[t]he smallest industries are... effectively precluded from the political process"). Another public choice explanation might be that agency actors and the industries they regulate will have repeat interactions. IAN AYRES \& JOHN BRAITHWAITE, RESPONSIVE REgulation: Transcending the DeREgulation DeBATE 54-55 (1992) (comparing this repeat interaction to a multiperiod prisoner's dilemma game). If that is the case, then one would expect patterns of cooperation which might, in the face of policy change, give rise to a systemic resistance to change, lest that upset a status quo that benefits both regulator and regulated industry. See id. (discussing how the conditions that encourage cooperation can also encourage capture and corruption).

20. For example, within the category of framing problems, one explanation could be that the costs of environmental policy are more easily identified and visualized than the environmental benefits, which tend to take on statistical forms. Shi-Ling Hsu, The Identifiability Bias in Environmental Law, 35 FLA. ST. U. L. REV. 433, 440, 443-44 (2008) (describing the statistical links between air pollution and health problems as "weak attractors of sympathy").

21. There are obviously conflicting accounts of whether the science of climate change is sufficient or not, but most informed observers of the climate change debate would agree that the risk of inaction is unjustifiable. A summary of the controversy can be found in Shi-Ling Hsu, A Prediction Market for Climate Outcomes, 83 U. Colo. L. REV. 179, 181-89 (2011) (explaining how the distrustful general public has an "inflated perception of the extent of disagreement among climate scientists"). 
some explanatory power, a theory of how capital impedes energy and environmental policy reform is the most broadly applicable. This Article sets forth a theory that is more specific than most public choice explanations and broader than most psychological explanations. Just about every proposed reform to address a latent environmental problem has emerged in the middle of the economic life of some form of capital and posed a threat to some individual, firm, or industry that had capital invested in the status quo. ${ }^{22}$ Every proposed reform of significance creates losers; this Article explains how they lose and how much they will resist losing. If the continued exploitation of capital creates latent externalities that were not appreciated (or were consciously ignored) at its time of formation, a split in interests emerges: cessation of use of the capital may be desirable from the social point of view, but the owner of the capital will want to continue to use the capital. This simple story is, in part, the story of almost every latent externality ever created.

A particularly salient example of this dynamic revolves around coal-fired electricity generation. Long-lived industrial capital such as coal-fired power plants played an important role in generating wealth throughout the world by providing low-cost electricity. ${ }^{23}$ The low costs were made possible by abundant supplies of coal that could be extracted at relatively low costs. ${ }^{24}$ Thousands of coal-fired power plants were built, and a vast extraction and distribution network was created to mine coal and deliver it to these power plants. ${ }^{25}$ Over time, however, a great deal of information has emerged suggesting that although the private costs of mining and burning coal are low, these direct costs are swamped by the social and environmental costs of coal mining and combustion. ${ }^{26}$ Also, new technologies and new

22. See infra note 100 and accompanying text (explaining that reform will only take place when capital assets have "remaining life").

23. For a general history of coal, see generally BARBARA FREESE, COAL: A HUMAN HISTORY (2003).

24. Id. at 6-7; Sean Patrick Adams, The US Coal Industry in the Nineteenth Century, ECON. HISTORY ASS'N, http://www.eh.net/encyclopedia/the-us-coal-industry-inthe-nineteenth-century-2/ (last visited Feb. 6, 2014) (describing coal in the nineteenth century as "cheap and efficient" and detailing the innovations in coal mining that facilitated extraction).

25. FREESE, supra note 23, at 118-26.

26. Epidemiological work undertaken over decades has shown that by far, the greatest cost of coal combustion is in the human toll of premature deaths occurring due to fine particulate matter emissions. See supra note 14 and accompanying text (discussing research linking concentrations of fine particulate matter to premature mortalities). For an estimate of the total damages from coal combustion, see Roberta Mann, Another Day Older and Deeper in Debt: How Tax Incentives Encourage Burning Coal and the Consequences for Global Warming, 20 PaC. McGeorge Global Bus. \& Dev. L.J. 111, 
sources of energy (most prominently natural gas) have emerged suggesting that coal is not even the cheapest fossil fuel for generating electricity. ${ }^{27}$ But the sprawling network of coal production, distribution, and combustion is fixed. It cannot be easily redeployed in a low-carbon economy. ${ }^{28}$ This capital rigidity has created a huge number of parties with a tremendous stake in its continued existence. ${ }^{29}$

This Article sets out a theory of capital that explains how legal rules and institutions create resistance to reform, especially attempts to address environmental externalities. Part II of this Article sets out a working definition of the term "capital." This Part also briefly describes the three different types of capital considered in this Article: physical, human, and social capital. Part III of this Article sets out examples of how capital impedes reform attempting to address latent externalities. Part IV

118-25 (2007) (listing external costs on society resulting from the use of coal, including worker accidents, acid precipitation, and loss of topsoil); Muller, Mendelsohn \& Nordhaus, supra note 18, at 1661, 1665 tbl.2 (discussing the Laden et al. study and showing, using integrated assessment economic models, external damages of $\$ 53.4$ billion, which is 2.2 times greater than the value added by coal-fired electricity generation).

27. See Electricity from Non-Hydroelectric Renewable Energy Sources, U.S. ENVTL. PROT. AGENCY, http://www.epa.gov/cleanenergy/energy-and-you/affect/non-hydro.html (last updated Sept. 25, 2013) (describing how biomass is better for the environment than burning coal). Natural gas has long been known to be less polluting than coal and, at least in the environmental sense, a superior fossil fuel. See Electricity from Natural Gas, U.S. ENVTL. PROT. AGENCY, http://www.epa.gov/cleanenergy/energy-and-you/affect/naturalgas.html (last updated Sept. 25, 2013). More recently, the emergence of hydraulic fracturing technology has rendered natural gas inexpensive enough to rival coal as the fuel of choice for electricity generating firms. See, e.g., Electric Power Monthly, U.S. ENERGy INFo. ADMin., U.S. DEP'T OF ENERGY (Sept. 20, 2013), http://www.eia.gov/electricity/monthly/epm_table_grapher.cfm?t=epmt_1_01 (showing net generation from natural gas approaching that of coal); Ken Silverstein, Obama Trying to Escape Political Fallout from Natural Gas Fracking Proposals, ForBES (Sept. 6, 2013), http://www.forbes.com/sites/kensilverstein/2013/09/06/obama-trying-to-escape-political-

fallout-from-natural-gas-fracking-proposals/ (describing how the Obama administration discourages coal-fired power plants and encourages natural gas, which is easier to access due to hydraulic fracturing, or "fracking").

28. Coal-fired power plants can be converted to natural-gas-fired power plants, but the conversion is usually too costly and burdensome. See, e.g., ERIC WILLIAMS ET AL., Climate Change Policy P'ship, Duke Univ., A Convenient Guide to Climate Change Policy AND TECHNOLOGY 37, 39-40 (2007), available at http://www.nicholas.duke.edu/ ccpp/convenientguide/PDFs/ClimateBook.pdf (giving examples of coal-fired power plants that have been "repowered," but conceding that "retiring all coal-fired power plants and replacing them with less carbon-intensive plants is not economically or politically feasible"); Daniel Cusick, Study: Switch From Coal to Gas Poses Some Risks for Utilities, MidWEST ENERGY NewS (Sept. 12, 2013), http://www.midwestenergynews.com/2013/09/ 12/study-converting-coal-to-gas-poses-some-risks-for-utilities/ (describing how investments in conversion of a plant are risky due to the uncertain future of the energy market, particularly the impact of regulations).

29. See infra Part IV.B (discussing how further capital formation in the mining industry would thwart much-needed policy reform). 
explains how current laws and governmental structures either overpromote the formation of capital or overprotect it once it is formed or acquired. Part V argues for a refocusing of government subsidies on true public goods. Specifically, this Part argues that government policy should focus more on network goods, and not just on capital projects that lower commodity prices. This Article then concludes with some general observations on laws affecting the formation and protection of capital.

\section{WHAT IS CAPITAL?}

The term "capital" has an almost universally positive connotation. ${ }^{30} \mathrm{~A}$ fair amount of government policy seems to be oriented toward promoting the formation and acquisition of capital. Scattered liberally throughout the Internal Revenue Code are generous provisions to assist with the formation and acquisition of capital, ${ }^{31}$ especially for small businesses. ${ }^{32}$ President Obama's economic stimulus packages of 2008 and 2009 included temporary provisions to allow an increased tax deduction for certain capital equipment. ${ }^{33}$ There is even a Washington-based advocacy group that extols the virtues of

30. The Future of Capital Formation: Hearing Before the Comm. on Oversight \& Gov't Reform, 112th Cong. 4 (2011) (statement of Mary Schapiro, Chairman, U.S. Securities and Exchange Commission), available at http://www.gpo.gov/fdsys/pkg/CHRG112hhrg70517/pdf/CHRG-112hhrg70517.pdf ("Facilitating capital formation, protecting investors, and maintaining fair, orderly, and efficient markets is the mission of the SEC. Cost-effective access to capital for companies of all sizes plays a critical role in our national economy, and companies seeking access to capital should not be overburdened by unnecessary or superfluous regulations."). Also, Section 2 of the Securities Act of 1933 regarding "consideration of promotion of efficiency, competition, and capital formation" provides, in part:

Whenever pursuant to this subchapter the Commission is engaged in rulemaking and is required to consider or determine whether an action is necessary or appropriate in the public interest, the Commission shall also consider, in addition to the protection of investors, whether the action will promote efficiency, competition, and capital formation.

15 U.S.C. $\S 77 b(b)(2012)$.

31. See, e.g., Robert E. Hall \& Dale W. Jorgenson, Tax Policy and Investment Behavior, 57 AM. ECON. REV. 391, 391, 410 (1967) (attributing investment booms in the 1950 s and 1960s to changes in tax policy).

32. See, e.g., Douglas Holtz-Eakin, Public Policy Toward Entrepreneurship, 15 SMAll Bus. ECON. 283, 288-89 (2000) (describing such benefits for small businesses including, for example, possible yearly deductions of up to $\$ 17,500$ in capital expenditures); Philip F. Zeidman et al., The Small Business Investment Company-A Tool for Economic Self-Help, 21 BUs. LAW. 947, 950, 961 (1966) (describing the special tax benefits for small business investment companies, such as creating a debt reserve of up to ten percent of outstanding loans and special rules for the deduction of dividends).

33. Economic Stimulus Act of 2008, Pub. L. No. 110-185, § 103, 122 Stat. 613, 61819; American Recovery and Reinvestment Act of 2009, Pub. L. No. 111-5, § 1201, 123 Stat. $115,333-35$. 
capital formation for its own sake, the American Council for Capital Formation. ${ }^{34}$ The worship of capital may be even more pronounced in capital-poor developing countries, for which prescriptions center upon making capital more available. ${ }^{35}$ It is the formation of capital, everyone seems to believe, that creates low commodity prices and broadly distributed benefits, unleashing the industry and entrepreneurship of individuals and firms in an economic society.

And yet, despite our universal admiration for capital, a precise and widely accepted definition of capital is elusive. Adam Smith defined it as "[h]is ... stock .... which, he expects, is to afford him [his] revenue." ${ }_{6}$ In a similar vein, Robert Solow has defined it in passing as generically a "stock of produced or natural factors of production that can be expected to yield productive services for some time." 37 Gregory Mankiw posits capital as current consumption forgone to produce more income tomorrow. ${ }^{38}$ Undergraduate textbooks simply model production as a function of just two types of inputs: capital and labor. ${ }^{39}$ This dichotomy is a gross oversimplification, of course. Labor is required to build the capital in the first place; in that sense, capital can simply be thought of as stored labor. ${ }^{40}$

34. Economic Policy, AM. COUNCIL FOR CAPITAL FORMATION, http://accf.org/ publications/\#economic-policy-tab (last visited Feb. 6, 2014).

35. Hernando de Soto's The Mystery of Capital propounds a theory that people in developing countries fail to accumulate wealth because their property cannot be leveraged as capital the way that it can in developing countries. HERNANDO DE SOTO, THE MYSTERY of CAPITAL: Why CAPITALiSM TRIUMPHS IN THE West AND FAIls EverYwhere Else 5-6 (2000). Muhammad Yunus won a Nobel Peace Prize for his pioneering work in the business of microfinance in poor communities, making small loans to collateral-poor entrepreneurs. Muhammad Yunus-Facts, NOBEL PRIZE, http://www.nobelprize.org/ nobel_prizes/peace/laureates/2006/yunus-facts.html (last visited Jan. 18, 2014).

36. Adam Smith, AN InQUiRy into the Nature AND CAUSEs of the Wealth of NAtions 162 (Kathryn Sutherland ed., Oxford Univ. Press 1998) (1776).

37. Robert M. Solow, Notes on Social Capital and Economic Performance, in SocIAL CAPital: A Multifaceted Perspective 6 (Partha Dasgupta \& Ismail Serageldin eds., 2000).

38. Mankiw, supra note 2, at 293.

39. David Gordon \& Richard Vaughan, The Historical Role of the Production Function in Economics and Business, AM. J. Bus. EdUC., Apr. 2011, at 25, 25. The nowfamiliar Cobb-Douglas formulation, $Y=A L^{a} K^{\beta}$, is a relation which every economics student learns about in undergraduate economics, and it posits production as a function of the quantity and productivity of just two types of inputs: labor $(L)$ and capital $(K)$. See generally Cobb \& Douglas, supra note 1 (deriving and discussing the Cobb-Douglas formula); Douglas, supra note 1 (discussing the inputs of labor and capital within the Cobb-Douglas formula). Robert Solow's fundamental neoclassical growth model posits growth as a general function of labor, capital, and technology, the latter being a multiplier that makes the other two inputs more productive. Solow, supra note 2 , at $65-66,85$.

40. Hernando de Soto notes that capital "must be fixed and realized in some particular subject which lasts for some time at least after that labour is past. It is, as it 
These, and a number of other definitional complexities, have led to some more conceptual and less rigid formulations of capital. Gary Becker has, in his seminal work, married labor and capital into "human capital" to denote the amount of human training and education that is undertaken to produce other things (or services). ${ }^{41}$ Indeed, a broad notion of capital is central to the thesis of this Article, as the mystery of how capital retards environmental policy reform can only be unlocked when considering the many forms of capital invested in polluting behavior.

This Article sets forth a working definition that does not seek to bridge or synthesize differences among the economic giants that have considered this topic. For purposes of this Article, I define capital as a long-lived asset that generates a stream of benefits. Capital is long-lived in the sense that it is meant to be durable and undergo sustained use over a period of time or more generally over a quantity of production. ${ }^{42}$ Capital generates a stream of benefits because that is why it is obtained in the first place. ${ }^{43}$

Capital is not necessarily costly. In some cases, capital is accumulated without effort or cost. ${ }^{44}$ But even in such cases of windfall capital, a possessor's defense of that capital can be as vigorous as that of costly capital. ${ }^{45}$ The costliness of capital may,

were, a certain quantity of labour stocked up and stored to be employed, if necessary, upon some other occasion." DE SOTO, supra note 35, at 42 (internal quotation marks omitted).

41. Gary S. Becker, Human Capital: A Theoretical and Empirical Analysis, WITH SPECIAL REFERENCE TO EDUCATION 16-17 (3d ed. 1993) (expounding on the concept of "human capital" and claiming that "[e]ducation and training are the most important investments in human capital").

42. See Paul S. Adler \& Seok-Woo Kwon, Social Capital: Prospects for a New Concept, 27 ACAD. MGMT. REv. 17, 25 (2002) (defining all forms of capital as "long-lived asset[s] into which other resources can be invested, with the expectation of a future ... flow of benefits"); Solow, supra note 37, at 6 ("Generically, 'capital' stands for a stock of produced or natural factors of production that can be expected to yield productive services for some time.").

43. See, e.g., Franco Modigliani \& Merton H. Miller, The Cost of Capital, Corporation Finance, and the Theory of Investment, 48 AM. ECON. REV. 261, 265 (1958) (stating that a firm's assets will provide its shareholders with a "stream of profits" during a given period of time (internal quotation marks omitted)).

44. See, e.g., BECKER, supra note 41, at 21-22 (illustrating how human capital can be accumulated and developed through children's family and upbringing); Elinor Ostrom, Social Capital: A Fad or a Fundamental Concept?, in Social CaPiTAl: A Multifaceted PERSPECTIVE, supra note 37, at 172, 174 ("Many types of capital can be created without money, or with very little of it ....”).

45. See, e.g., Christopher L. Dyer \& Mark Moberg, The 'Moral Economy' of Resistance: Turtle Excluder Devices and Gulf of Mexico Shrimp Fishermen, 5 MAR. ANTHROPOLOGICAL STUD., no. 1, 1992, at 18, 20-21 (explaining how fishermen develop their skill sets and "vehemently resist perceived threats to livelihood"). 
for psychological reasons, inspire more spirited defense, but for purposes of this Article is not a predicate to the points made in this Article.

I consider three kinds of capital: physical, human, and social. 46 There are many other kinds of assets to which the label of "capital" has been attached. ${ }^{47}$ But these three forms of capital, as I describe them below, are the forms of capital that have played a prominent role in retarding policy reform to address latent environmental externalities. ${ }^{48}$

Physical capital is capital that takes on a tangible, physical form. ${ }^{49}$ For example, a power plant, with a useful life of at least forty years, ${ }^{50}$ is an asset that generates a stable stream of revenues in the form of consumer electricity payments. Indeed, ensuring that environmental regulation does not threaten the size or the continuity of that stream of benefits occupies a considerable amount of attention from the owners of that capital. ${ }^{51} \mathrm{~A}$ stable regulatory and price environment is the ideal

46. Many scholars consider social capital to be a recent addition to the three previously widely-accepted forms of capital: physical, human, and natural. See Ostrom, supra note 44, at 172-76; Norman Uphoff, Understanding Social Capital: Learning from the Analysis and Experience of Participation, in Social CAPITAL: A Multifaceted PERSPECTIVE, supra note 37, at 215, 215, 217 (noting that social capital is a recent conceptualization of capital, which traditionally has consisted of "the standard three categories of capital"-physical, natural, and human).

47. Natural resources and environmental conditions can constitute "natural capital." See, e.g., Ostrom, supra note 44, at 174, 182 (inferring that natural resources are a form of capital because the removal of natural resources can be detrimental to social capital); M.V. Russo, The Emergence of Sustainable Industries: Building on Natural Capital, 24 Strategic MGMT. J. 317, 320 (2003) (defining "natural capital" in terms of natural resources). Capital can also be financial. The term "capital markets" is commonly used to refer to equity markets, or stock markets, in which invested monies are hoped to generate a future benefit in the form of a stock dividend or an increased share value over time. See Eugene F. Fama, Efficient Capital Markets: A Review of Theory and Empirical Work, 25 J. FIN. 383, 383 (1970) ("The primary role of the capital market is allocation of ownership of the economy's capital stock."); Lindon J. Robison, A. Allan Schmid \& Marcelo E. Siles, Is Social Capital Really Capital?, 60 Rev. Soc. EcoN. 1, 7 (2002) (defining financial capital as "the symbols and rights associated with credit and money").

48. See discussion infra Part III.A-B. (describing how capital has encumbered policy reform in certain industries, which, in turn, has led to environmental problems).

49. See Ostrom, supra note 44, at 174 (providing examples of "physical capital" such as "buildings, roads, waterworks, tools, cattle and other animals, automobiles, trucks, and tractors").

50. For example, a recent regulation by Environment Canada to apply a new emissions performance standard for coal-fired power plants "at the end of their useful life" assumed a useful life of a power plant to be forty-five years. Reduction of Carbon Dioxide Emissions from Coal-Fired Generation of Electricity Regulations, 145 C. Gaz. 2779, 2783 (Can. Aug. 27, 2011), available at http://www.gazette.gc.ca/rp-pr/p1/2011/2011-0827/pdf/g1-14535.pdf.

51. See, e.g., Satish Joshi, Ranjani Krishnan \& Lester Lave, Estimating the Hidden Costs of Environmental Regulation, 76 ACCT. REV. 171, 173-74, 194 (2001) (providing an example of how industries consider the stream of benefits and costs 
environment, if not the sine qua non of the investment of such capital. $^{52}$ The costliness of physical capital such as a power plant, ${ }^{53}$ coupled with the long time horizons involved in paying for such capital, ${ }^{54}$ lends urgency to the task of monitoring and managing, to the greatest extent possible, the regulatory and price environments.

Human capital is most often thought of as education and training. ${ }^{55}$ Generally speaking, the higher the education, the greater the value of the human capital. ${ }^{56}$ Education can be costly, not only because of direct costs, but also because of the

when determining whether to bring old plants into environmental compliance or to shut them down).

52. See Alfred Marcus, J. Alberto Aragon-Correa \& Jonatan Pinkse, Firms, Regulatory Uncertainty, and the Natural Environmental, 54 CAL. MGMT. REV. 5, 8-9 (2011) (observing that when the "regulatory trajectory" is certain, industries and firms will have more stability in their investments).

53. Coal-fired power plants that entered service in 2010 have an estimated average “overnight" capital cost of $\$ 2,844$ to $\$ 3,565$ per kilowatt of capacity. See U.S. ENERGY Info. AdMin., U.S. DEP'T OF ENERGY, UPdATED CAPITAL COST Estimates For ELECTRICITY GENERATION PlANTS 3, 7 tbl.1 (Nov. 2010), available at http://www.eia.gov/ oiaf/beck_plantcosts/pdf/updatedplantcosts.pdf. The overnight capital cost is "an estimate of the cost at which a plant could be constructed assuming that the entire process from planning through completion could be accomplished in a single day." $I d$. at 2 n. 2 .

54. As a crude order-of-magnitude calculation, assuming a capacity rate of eightyfive percent-meaning that the plant runs at an average long-term capacity of eighty-five percent, an assumption made by the U.S. Department of Energy in calculating capital costs-a 500-megawatt power plant would generate 425 megawatt-hours every hour, every day, or 3,723,000 megawatt-hours per year. U.S. ENERGY INFO. ADMIN., U.S. DEP'T OF ENERGy, LEVELIZED COST OF NEW GENERATION RESOURCES IN THE ANNUAL ENERGy OUTLOOK 2013, at 4 \& tbl.1 (2013), available at http://www.eia.gov/forecasts/aeo/er/pdf/ electricity_generation.pdf. Using the average 2011 nationwide retail price of electricity, $\$ 88.10$ per megawatt-hour, U.S. ENERGY INFO. ADMIN., U.S. DEP'T OF ENERGY, ANNUAL ENERGY REVIEW 2011, at 255 \& tbl.8.10 (2012), available at http://www.eia.gov/ totalenergy/data/annual/pdf/sec8_39.pdf, and subtracting out average operations and maintenance costs of $\$ 35.09$ per megawatt-hour, U.S. ENERGY INFO. ADMIN., U.S. DEP'T OF ENERGY, ElECTRIC POWER ANNUAL 2011, tbl.8.4 (2012), available at http://www.eia.gov/electricity/annual/pdf/epa.pdf, it would take 7.8 years to pay back the capital costs. Of course, this crude calculation omits many other costs, factors, and variables, including finance costs, transmission costs, and other expenses associated with running a power plant.

55. BECKER, supra note 41 , at 17.

56. See id. at 169-70 \& tbl.4, 223-24 \& tbl.17 (showing greater earning capacities for college graduates compared to high school graduates). Although the marginal returns to a college education have not always been historically higher than the marginal returns to high school education, the marginal returns to college education have always been positive. See Claudia Goldin \& Lawrence F. Katz, The Race Between Education and TECHNOLOGY 76, 78-79 \& tbl.2.5 (2008) (showing positive returns to college schooling); Richard Vedder, Universities and Income Equality: New Evidence and Conjectures, CHRON. HigheR EDUC. (Aug. 25, 2011), http://www.chronicle.com/blogs/innovations/ universities-and-income-equality-new-evidence-and-conjectures (discussing the "law of diminishing returns" as applied to higher education). 
opportunity costs of forgone income. ${ }^{57}$ Indisputably, human capital is valuable, as productivity is observed to be clearly and consistently greater in the presence of human capital. ${ }^{58}$ Thus human capital is, by itself, something that generates a stream of benefits, in the form of earnings that would not otherwise be realized.

Importantly, human capital need not be formal. While human capital is most easily conceived as formal schooling or onthe-job training, ${ }^{59}$ there are clearly many other forms of human capital. Human capital may be the acquired knowledge of some facet of resource extraction, or some operational expertise connected to a specific industrial process. The acquisition of human capital may not be part of any organized effort at all. Microsoft co-founder Bill Gates and Apple co-founder Steve Jobs, both college dropouts, owe a considerable amount of their success to human capital they acquired at early, formative stages of life. ${ }^{60}$ In almost all cases, human capital requires significant costs to obtain, has the potential to be long-lived, and can generate a long-lived stream of benefits. ${ }^{61}$

Finally, social capital, as it is conceived in this Article, consists of the variety of interpersonal and intra-organizational bonds that are formed when one signals to another that cooperation is sought. ${ }^{62}$ Among economists, there is some

57. See, e.g., Theodore W. Schultz, Capital Formation by Education, 68 J. PoL. ECON. 571, 573, 577 (1960) (stating that students incur opportunity costs while in college such as reduced leisure and forgone income from employment not requiring an education).

58. Theodore W. Schultz, Investment in Human Capital, 51 AM. EcoN. REV. 1, 3 (1961) (“ $[\mathrm{K}]$ nowledge and skill are in great part the product of investment and, combined with other human investment, predominantly account for the productive superiority of the technically advanced countries.”).

59. For example, Becker's original empirical work focuses on the measurable benefits of schooling and on-the-job training. See BECKER, supra note 41, at 17-21 (noting that the most important components of human capital are education and on-the-job training).

60. Malcolm Gladwell, Outliers: The Story of Success 50-54 (2008) (describing the "extraordinary series of opportunities" that Gates was presented with at an early age); WALTER ISAACSON, STEVE JobS 3-20 (2011) (illustrating how Steve Jobs acquired human capital at an early age by getting hands-on experience with computers and electronics).

61. See BECKER, supra note 41, at 117 (stating that human capital is expensive due to the high cost of education and the long period required to accumulate knowledge and skills); James S. Coleman, Social Capital in the Creation of Human Capital, 94 AM. J. Soc. 95, 116 (Supp. 1988) ("[T] he person who invests the time and resources in building up [human] capital reaps its benefits in the form of a higher-paying job, more satisfying or higher-status work, or even the pleasure of greater understanding of the surrounding world.").

62. See Ostrom, supra note 44, at 176 (defining "social capital" and noting that individuals can be more productive when activities are coordinated). 
controversy as to whether the term "capital" can be coherently applied to something like the social interactions that make up what is popularly referred to as social capital. ${ }^{63}$ For those economists that engage with the concept of social capital, the focus is typically on how it increases productivity. After all, what good would social capital be, apart from the psychological benefits of social belonging? ${ }^{64}$ If social capital is to have economic content, then it must have a role in economic performance.

What is different about social capital is that the social interactions that make up social capital do not primarily have economic motivations. The concept of social capital thus draws heavily from the work of Robert Putnam's Bowling Alone, ${ }^{65}$ which chronicles the decline of social institutions in the United States, the result of which is a lack of a social fabric that made many cooperative endeavors possible in the past. ${ }^{66}$ Putnam's argument is that social networks enhance political and civic life without consciously having these outcomes as objectives. ${ }^{67}$ The economic perspective is thus analogous to Putnam's argument: social capital enhances economic productivity without consciously having economic productivity as its primary goal. ${ }^{68}$

63. See, e.g., Kenneth J. Arrow, Observations on Social Capital, in SocIAL CAPITAL: A Multifaceted PeRspective, supra note 37, at 3, 3-4 (advocating the abandonment of "social capital" terminology); Robison, Schmid \& Siles, supra note 47, at 7-8 ("We don't need the new word 'social capital."); Solow, supra note 37, at 6-7 (criticizing the idea of "social capital" because the original meaning of "capital" was associated with physical, durable objects).

64. Economists argue that joining social networks have noneconomic benefits, and are at least in part the motivation for joining. See, e.g., Arrow, supra note 63, at 3 ("There is considerable consensus also that much of the reward for social interactions is intrinsic-that is, the interaction is the reward-or at least that the motives for interaction are not economic. People may get jobs through networks of friendship or acquaintance, but they do not, in many cases, join the networks for that purpose."); Robison, Schmid \& Siles, supra note 47, at 7-17 (explaining how some critics argue that social capital does not contain an opportunity cost, which is an essential component to true "capital," but arguing that social capital does in fact exhibit many of the qualities of "capital").

65. See Robert D. Putnam, Bowling Alone: The Collapse and Revival of AMERICAN COMMUNITY 351-52, 358 (2000) (discussing how social capital is intertwined with the concepts of liberty, tolerance, and equality).

66. Id. at 352-59 (positing that social capital began to decline in the 1960s when "tolerance and diversity blossomed," causing Americans to become "disconnected from civic life and from one another").

67. Id. at 359 ("[I]n high-social-capital states people from different social classes are equally likely to attend public meetings, to lead local organizations, and the like ....”).

68. See Arrow, supra note 63, at 4 ("The essence of social networks is that they are built up for reasons other than their economic value to the participants ...."); Ostrom, supra note 44, at 174 (observing that human-made capital, including social capital, is accumulated incidental to other activities and leads to more income). 
Drawing on the working definition of capital set forth in this Article, social capital is just another asset that is long-lived and can generate a long-lived stream of benefits. Of the three forms of capital considered in this paper, it is the least costly and timeconsuming to acquire, and the stream of benefits flowing from it consists of a number of intangible benefits, be it informational benefits or just the small favors and graces extended to those within a social fabric. ${ }^{69}$ These benefits can be extremely important. James Coleman provides a compelling example of the importance of social capital in the Jewish diamond merchant community, in which merchants entrust fellow merchants with diamonds worth very large amounts of money. ${ }^{70}$ The reason that thievery is nonexistent in this community, despite ample opportunity to engage in it, is explained by the social interconnectedness of the merchants. Stealing would result in ostracism from a community and forfeiture of social, family, and religious ties. ${ }^{71}$ Social capital thus often plays a vital economic role, lubricating mercantile relations while obviating the need for expensive and perhaps ultimately futile monitoring. ${ }^{72}$

Social capital could play a critical role in motivating poor, resource-based communities to fight regulation. In resourcebased communities otherwise lacking in physical or human capital, social capital is a more egalitarian form of capital, requiring few of the financial resources that are necessary and sometimes unavailable to socioeconomically disadvantaged groups. ${ }^{73}$ Strong social interconnectedness has been observed in a variety of fishing communities. ${ }^{74}$ As it happens, fishers are, even among resource industries, legendary for their resistance to regulation. ${ }^{75}$ As in the Jewish diamond broker example, trust and

69. See, e.g., Coleman, supra note 61 , at 98-99 (inferring that social capital requires fewer expenditures because it is formed through relations and interactions).

70. Id.

71. Id. at 99 .

72. See id. (observing that strong "family, religious, and community ties" yield relationships built on trust with little cost).

73. Putnam has written that "[h]istorically social capital has been the main weapon of the have-nots, who lacked other forms of capital." PUTNAM, supra note 65, at 359.

74. James M. Acheson, The Maine Lobster Market: Between Market and Hierarchy, 1 J.L. Econ. \& ORG. 385, 385-86 (1985); Sean R. Lauer, Entrepreneurial Processes in an Emergent Resource Industry: Community Embeddedness in Maine's Sea Urchin Industry, 70 RURAL Soc. 145, 156, 158-59, 162 (2005); James A. Wilson, Adaptation to Uncertainty and Small Numbers Exchange: The New England Fresh Fish Market, 11 BELL J. ECON. 491, 494-95 (1980).

75. See, e.g., Dyer \& Moberg, supra note 45, at 27-31 (examining the strong resistance among shrimp fishermen toward federal regulation); Shi-Ling Hsu, What Is a Tragedy of the Commons? Overfishing and the Campaign Spending Problem, 69 ALB. L. REV. 75, 128 (2005); Barton H. Thompson, Jr., Tragically Difficult: The Obstacles to 
reciprocity, the social capital that is formed from long-running relationships, have served a vital economic purpose for low-profit industries that cannot afford expensive or time-consuming monitoring efforts. ${ }^{76}$ Indeed, when social capital is low-when interconnectedness is not present-fishing communities that otherwise resemble other communities with high social capital function much less efficiently and are much less profitable. ${ }^{77}$

Social capital is still, in a sense, costly to obtain, as it requires time and effort to earn trust and to credibly signal the intent to cooperate. Like physical and human capital, once created by sustained cooperation or assistance, social capital can yield a stream of benefits that becomes extremely valuable and in some cases, economically necessary. Even though social capital is not readily monetizable, it can be even more valuable to its holder than tangible assets like physical capital. ${ }^{78}$ Perhaps more significantly, it can be the only form of capital held by some individuals and some groups. ${ }^{79}$

To be sure, most capital contains combinations of all three kinds of capital. ${ }^{80}$ Physical capital contains the embedded human capital required to design and build a highly sophisticated and expensive piece of equipment. Social capital is invariably embedded as well, in the form of the informal cooperative arrangements that are needed for a large-scale endeavor to be productive. Physicality is just the most obvious aspect of capital.

\section{HOW CAPITAL IMPEDES REFORM}

Exactly how does the presence of excess capital impede policy reform? This Part briefly describes the capital that is

Governing the Commons, 30 ENVTL. L. 241, 244-45 (2000) ("Many resource users, moreover, might conclude that they are better off in a commons free-for-all than in a world constrained by property rights, unified management, or regulation.").

76. Coleman, supra note 61, at 98-99; Wilson, supra note 74, at 495 ("[T]he economic significance of a trustworthy relationship lies in the reduction in [an individual's] costs of verifying the statements of the other party. This reduction in transactions costs creates strong economic forces which favor the extension of the bilateral relationship to exchanges of other goods and services.”).

77. See Sean R. Lauer, Exchange Relationships in Inshore Fisheries, 23 Soc. F. 503, 506-07 (2008) (discussing how low social capital creates distrust and opportunism, causing increased transaction costs due to "frequent misunderstandings, conflicts, delays and breakdowns, and increased investment in the monitoring of exchanges").

78. Adler \& Kwon, supra note 42, at 22, 29-30; see PUTNAM, supra note 65, at 359 (showing that groups of individuals lacking the means to obtain expensive forms of capital rely heavily on social capital).

79. PUTNAM, supra note 65, at 359.

80. Coleman, supra note 61 , at 100-01 (describing the linkage between physical, human, and social capital). 
embedded in a number of industries that have been belatedly shown to cause a number of environmental problems. This Part then sets out a simple model showing how relatively small incentives for capital formation might lead to large increases in capital investment, creating a tendency to "super-size" capital.

\section{A. Overcapitalization as a Drag on Environmental Reform}

The thesis of this Article is that legal rules and institutions have helped create too much capital, which has led to a heightened resistance to legal reform. Legal rules and institutions have overpromoted the formation of capital that is later discovered to cause latent environmental harms. ${ }^{81}$ Even after the latent environmental harms come to light, laws have overprotected capital at the expense of environmental quality. ${ }^{82}$ This is at least in part the story of how almost every environmental externality has been allowed to persist longer than a rational society would have allowed. ${ }^{83}$ In some way, capital has gotten in the way of solving almost every environmental problem in the history of humankind. ${ }^{84}$

It is important to consider capital in its varied forms, not just the physical capital-the bricks and mortar that are easily priced and monetizable-but the human and social capital that is intertwined with industrial practices and processes. The

81. See, e.g., Shi-Ling Hsu, The Real Problem with New Source Review, 36 EnVTL. L. REP. 10,095, 10,096-98 (2006) (discussing "grandfather clauses" and how such laws have permitted industries to infuse more capital into older facilities, leading to environmental problems); Heidi Gorovitz Robertson, If Your Grandfather Could Pollute, So Can You: Environmental "Grandfather Clauses" and Their Role in Environmental Inequity, 45 CATH. U. L. REV. 131, 168-70 (1995) (suggesting that "grandfather clauses" have allowed industries to opt out of complying with environmental regulations, thus avoiding expensive capital outlays and causing further environmental damage).

82. See, e.g., Robertson, supra note 81, at 168-70 (asserting that laws such as "grandfather clauses" have overprotected capital at the expense of environmental harm).

83. Id. (advocating that the allowance of capital-protective laws prolongs environmental harms).

84. See, e.g., Cees van Beers \& Jeroen C.J.M. van den Bergh, Environmental Harm of Hidden Subsidies: Global Warming and Acidification, 38 AMBIO 339, 339-41 (2009) (explaining how reliance on government subsidies, a form of capital, have prolonged environmental emissions problems); R.T. Paine et al., Trouble on Oiled Waters: Lessons from the Exxon Valdez Oil Spill, 27 AnN. REv. ECOlOGy \& Systematics 197, 222, 228 (1996) (discussing how then-existing capital was ineffective to clean up the Exxon Valdez oil spill and suggesting superior capital); Lawrence C. Smith, Jr., L. Murphy Smith \& Paul A. Ashcroft, Analysis of Environmental and Economic Damages from British Petroleum's Deepwater Horizon Oil Spill, 74 ALB. L. REV. 563, 565, 572-74 (2010) (attributing lack of physical and human capital, such as clean-up crews, vessels, and equipment, to the Deepwater Horizon oil spill's damaging effects, as well as lack of social capital in the form of blocking aid from countries that had offered to help with the cleanup). 
operation of physical capital to generate wealth requires a tremendous amount of human capital and industry-specific know-how. In addition, any endeavor of any reasonable size requires informal cooperation and the development of a network of social capital. The importance of such human and social capital is likely to be understated because their acquisition costs will generally not reflect their intrinsic value. ${ }^{85}$ For individuals possessing human capital that would be devalued by changes in industrial practices (such as oil rig or oilfield workers), or social capital that is specific to a small town that is predicated on a specific practice (such as that of a fishing or coal-mining community), their role in an anachronistic industry may be the only realistic source of income or sustenance. If, as is very often the case, these kinds of human or social capital may not be transferred to another setting, the switching costs for these people are essentially infinite. Were the source of income in these industries and communities to dry up, these people would essentially lose everything. That desperation may be a false perception, but for purposes of explaining the level of resistance to reform, it may as well be reality.

When these broader forms of capital are considered, it becomes less of a mystery as to why policy reform can be so politically and legally painful. Cost-benefit analyses do not capture the full array of perceived costs: the losses to human and social capital occurring after environmental regulation (or some other economic change) are highly salient to those possessing it, and far exceed any monetizable amount. ${ }^{86}$ And yet, there is no basis for taking such human and capital costs into account, or for compensating the holders of such capital; there is no inherent societal value of human or social capital if it is specific to an anachronistic industry. ${ }^{87}$

Overcapitalization plays a central role in the greatest environmental problem and market failure ever: global climate

85. See Adler \& Kwon, supra note 42, at 22 (stating that social capital is not "amenable to quantified measurement"); Mankiw, supra note 2, at 293-94 (asserting that human capital has the potential to be underestimated due to the complexity of valuing its variables).

86. See Jessica Crowe, The Role of Natural Capital on the Pursuit and Implementation of Economic Development, 51 Soc. PERSP. 827, 833 (2008) (inferring that environmental regulations can have negative impacts on communities, including social and human capital aspects); David S. Reay, Costing Climate Change, 360 PHIL. TRANSACTIONS ROYAL SOC'Y 2947, 2948-49 (2002) (observing that cost-benefit analyses with respect to climate change are not always able to reflect all of the social, technological, or environmental costs of emissions).

87. See Adler \& Kwon, supra note 42, at 22 (positing that social capital costs are difficult to monetize); Mankiw, supra note 2, at 293-94 (inferring that human capital costs are oftentimes undervalued). 
change. ${ }^{88}$ Developed economies have developed largely because of capital-intensive energy sectors. ${ }^{89}$ Thanks to sprawling energy infrastructures, fossil fuels are efficiently extracted, transported, and burned to generate energy at low prices. The problem is that greenhouse gas emissions from fossil fuel-based economies threaten to irreversibly and catastrophically warm the planet. ${ }^{90}$ Coal, the most carbon-intensive of the fossil fuels, continues to play a central role in energy provision. ${ }^{91}$ As noted briefly above, ${ }^{92}$ strong convincing evidence exists that coal combustion, given its social and environmental costs and its contribution to climate change, is simply no longer worth it..$^{93}$ And yet, coal combustion persists. Most energy forecasts project an increase in coal production. ${ }^{94}$ The world's stock of coal-fired power plants, with a combined value in the trillions of dollars, ${ }^{95}$ are not about to be abandoned. And it is not only the existing stock of coal-fired power plants that comprise the sluggish capital, but the human and social capital that is locked into a fossil fuel-centered way of doing things may ultimately consign the world population to living on a climate-changed planet.

All this is to say that capital, in all its forms, has played a special role in blocking environmental law and policy reform.

88. Nicholas Stern, the author of the Stern Review on the Economics of Climate Change, has called climate change the "greatest market failure the world has seen." Nicholas Stern, The Economics of Climate Change: The Stern Review xviii, 4, 27 (2007) (attributing climate change to human activities); supra notes 81-82 and accompanying text (discussing how overcapitalization helped perpetuate the harmful effects of greenhouse emissions).

89. See Michal C. Moore, Renewable Technologies to Power and Empower the Developing World, 16 COLO. J. INT'L ENVTL. L. \& POL'Y 377, 378, 383-90 (2005) (discussing energy's importance to developed and developing nations).

90. For a brief review of the voluminous literature on greenhouse gases and the risks of climate change, see HENSON, supra note 13, at 20.

91. Id. at 289-90.

92. See supra notes $23-27$ and accompanying text.

93. Even the most conservative estimates of the costs of climate change, coupled with other externalities, suggest that the benefits of this anachronistic industry are far exceeded by the costs. See, e.g., Muller, Mendelsohn \& Nordhaus, supra note 18, at 1665 (showing that coal plants have damages and costs that exceed the benefits).

94. U.S. EnERgy InFo. AdMin., U.S. DeP'T of EnERgy, AEO2014 EARLY RELEASE OVERVIEW 17-18 tbl.1 (2014), available at http://www.eia.gov/forecasts/aeo/er/pdf/0383er (2014).pdf.

95. A very rough estimate of the value of the stock of the world's coal-fired power plants can be obtained by multiplying world capacity, IEA ENERGY TECH. NETWORK, COAL-FIRED POWER (2010), available at http://www.iea-etsap.org/web/E-TechDS/PDF/E01coal-fired-power-GS-AD-gct.pdf; Electricity Generating Capacity, U.S. ENERGY INFO. ADMIN., U.S. DEP'T OF ENERGY (Jan. 3, 2013), http://www.eia.gov/electricity/capacity/, by a weighted average of overnight costs, weighted by plant location, INT'L ENERGY AGENCY, Projected Costs of Generating Electricity 2010, at 60 (2010). This back-of-theenvelope calculation is $\$ 3.6$ trillion USD. 
Perhaps more than even the stickiness of physical capital, environmental policy reform has bumped up against human and social capital that has become specialized to a specific industry or practice. These forms of capital can come to represent the very identity of a firm, person, or group. Destroying that capital can appear to be tantamount to destruction of that firm, person, or group. Resistance to reform will naturally be vigorous.

\section{B. A Model of How Capital Impedes Reform}

To see how this overcapitalization can lead to policy inertia, consider a simple stylized example of two types of investments: a low-capital-cost, low-benefit-stream investment, and a highcapital-cost, high-benefit-stream investment. The goal of any acquisition of any capital is to enjoy a stream of future benefits, but along with a higher stream of future benefits comes the risk that the future benefits may not fully materialize (for example, due to an unfavorable change in the regulatory or economic environment). Absent risk, the long-term value of the highcapital-cost, high-benefit-stream investment is greater. ${ }^{96}$ In this simple example, the only reason to choose a low-capital, lowprofit strategy over high-capital, high-profit strategy is the avoidance of risk. Of course, this abstracts away from many other determinants of capital ownership, like access to capital and discounting, and abstracts away from many other attributes of capital ownership, like market power and signaling benefits or detriments (like prestige or scorn). But heuristically, it is reasonable to work from the simplifying assumptions that the only reason to take on more expensive capital and the attendant risk is to generate a larger stream of benefits.

These two strategies are graphically depicted in Figure 1. Two different firms make a capital investment at an initial investment cost, $\boldsymbol{C 1}$, for the high-capital, high-profit strategy, and $\boldsymbol{C 2}$, for the low-capital, low-profit strategy. The cost of capital instantly drives down firm profitability, but capital generates a revenue stream that increases firm profitability as sales of the produced good generate revenues to pay back the cost of capital. In Figure 1, the profitability of the firms, i.e., the cumulative sum total of firm revenues and expenses, is graphed as a function of $q$, the quantity of sales. This cumulative profit line-the solid line for the high-capital, high-profit strategy-has

96. "Risk" is defined as "a chance of injury or loss." Elke U. Weber \& Richard A. Milliman, Perceived Risk Attitudes: Relating Risk Perception to Risky Choice, 43 MGMT. SCI. 123, 128 (1997). 
a steeper slope than the dotted line than that for the low-capital, low-profit strategy. Figure 1 represents the simple case in which the price and operating costs are constant for all units sold, so that profitability is linear in $q$. In an even simpler case, sales would be uniform over units and also over time, so that the horizontal axis could be time and the payback period represented by the point in time at which the profitability crosses the horizontal axis.

Ultimately, capital generates a cumulative profit. Assuming the expected life of the capital in both cases to be $\boldsymbol{h}$, the cost of risk associated with the high-capital, high-profit strategy is $r$. This also abstracts away from considerations having to do with discounting.

\section{Figure 1}

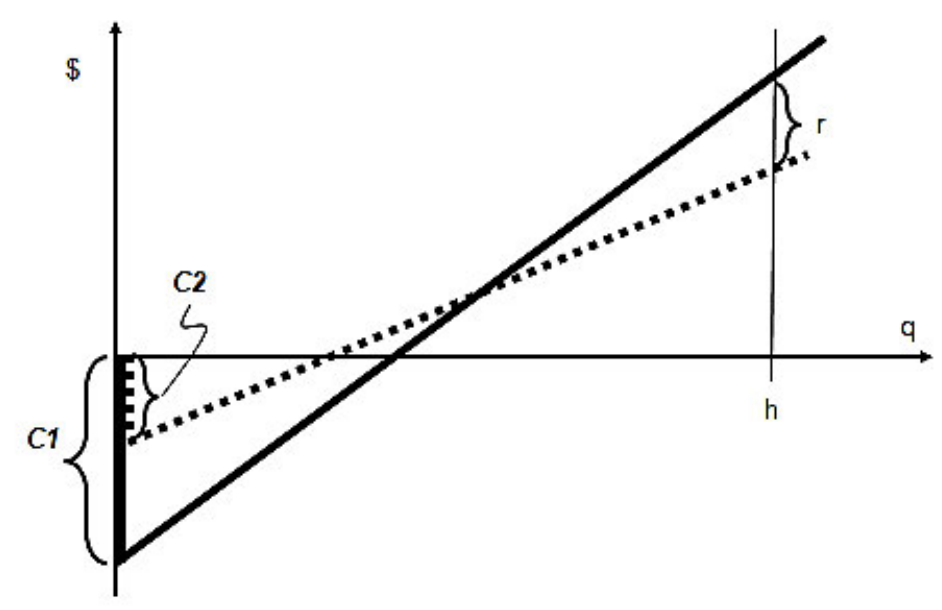

Ex ante, the cost of risk is simply a premium that is assumed by the firm adopting a high-capital, high-profit strategy. The premium compensates for the risk of a regulatory change that, in this simple case, renders the capital obsolete and valueless. So if a firm is risk-taking, it adopts the highcapital, high-profit strategy because the risk premium is sufficient compensation for the risk. Relatively risk-averse firms will opt for the low-capital, low-profit strategy. In Figures 2a and $2 \mathrm{~b}$ below, a regulatory change that renders the capital obsolete and valueless occurs when the firm has sold $\boldsymbol{x}$ units. The losses for the high-capital, high-profit strategy and the low- 
capital, low-profit strategy are shown in Figures $2 \mathrm{a}$ and $2 \mathrm{~b}$ below, respectively, as $\boldsymbol{L} \mathbf{1}$ and $\boldsymbol{L} \boldsymbol{2}$.

Figure 2a.

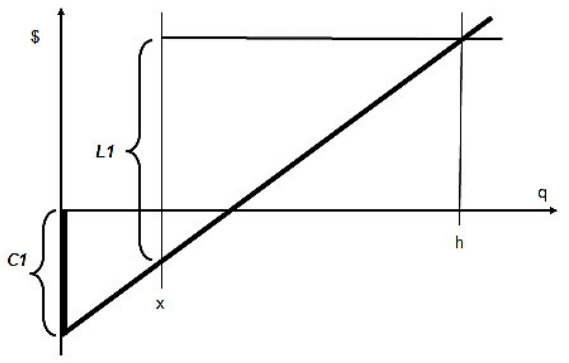

Figure 2b.

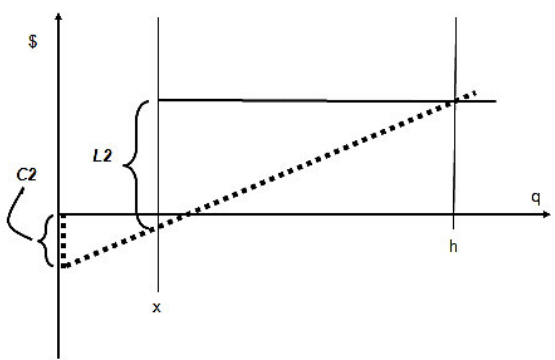

It is thus not the capital itself that industries, firms, and individuals fight vigorously to protect; it is the expected stream of benefits that inspires such vigorous defense. It so happens that most of the time we should expect that the more expensive the capital, the greater the stream of benefits. But that would be an imprecise conclusion. Expected benefits could well be capitalized into a valuation of capital, but far from being universally true, there is ample reason to suspect that capital is rarely perfectly priced to reflect the expected stream of benefits. ${ }^{97}$ Ultimately, it is the hoped-for stream of benefits that a firm, having acquired capital, will struggle to protect; it will expend any amount up to the value of the hoped-for but lost stream of benefits. ${ }^{98}$

Obviously, the loss suffered by an unfavorable change in the legal or economic environment is greater in the high-capital, high-profit scenario; there is a larger stream of benefits to lose. All other things being equal, as long as the high-capital, highprofit strategy yields higher marginal profits (again, this is assumed, because in this simple model there would otherwise be no reason to expend higher amounts of capital), the loss $\boldsymbol{L} \boldsymbol{1}$ will always be greater than the loss $\boldsymbol{L} \boldsymbol{2}$.

What is nonintuitive about the role of capital is the ex post amplification of the importance of the initial investment. Ex ante, the equilibrium cost of the risk is $r$. Ex post, however, once the

97. See, e.g., Franklin M. Fisher, On the Misuse of the Profits-Sales Ratio to Infer Monopoly Power, 18 RAND J. ECON. 384, 385, 392-94 (1987).

98. See Patrick Gaughan, Paul Lerman \& Donald Manley, Measuring Damages Resulting from Lost Functionality of Systems, J. LEGAL ECON., July 1993, at 11, 14-17 (describing capital budgeting techniques which weigh the current investment expenditure with the future value of the stream of benefits that investment will likely produce). 
capital is sunk, the stake is not just $r$, nor is it just the cost of capital. After the initial investment in capital, the risk of loss is equal to the expected stream of benefits. In order to combat such a loss, the owner of capital will expend any amount of money up to the expected loss ( $\boldsymbol{L} \mathbf{1}$ or $\boldsymbol{L} 2)$, which could well exceed the cost of the capital (C1 or $\boldsymbol{C} 2)$. So the amount of money spent on resisting policy change can be highly sensitive to initial decisions on capital investment. Just a subtle nudge, such as that provided by an obscure legal provision, can magnify differences in capital investment and lead to a very different world in terms of incentives to resist policy change.

Whether a firm chooses the high-capital, high-profit strategy or not thus has profound implications for economic efficiency. Put simply, the greater the value of the capital, the greater the threat of obsolescence for the firm owning the capital, and the greater efforts it will undertake to resist reform. An overcapitalized society will be a society in which there are more efforts to resist reform. Because capital in its various forms regularly experiences obsolescence, ${ }^{99}$ a capital-protecting society is a society that is less agile and less receptive to reform that threatens the value of that capital.

Note that losses $\boldsymbol{L} \mathbf{1}$ and $\boldsymbol{L} \mathbf{2}$ are only fully realized if the capital is "stranded," or unsusceptible of redeployment. More generally, the problem of avoiding loss can be considered as a problem with switching costs, and the losses $\boldsymbol{L} \mathbf{1}$ and $\boldsymbol{L} \boldsymbol{2}$ can be more generally considered the net costs of being forced (economically or by regulation) to switch capital to a new use. $\boldsymbol{L} 1$ and $\boldsymbol{L} \mathbf{2}$ are thus the lesser of switching costs and the complete economic loss of a stream of benefits.

This theory of capital-protecting offers insight into a further subtlety. When there is human or social capital involved, the monetization of a stream of benefits could appear quite small in comparison with the value of physical capital. But when the stream of benefits generated by that human or social capital is perceived (accurately or not) to be the only possible source of income, the marginal value of the stream of benefits generated by that human or social capital can be extremely high to the capital holder, perhaps even infinite. Defense of this kind of capital could be very vigorous.

In sum, capital will always pose a barrier to policy reform because policy reform will always take place when some capital

99. For example, one form of capital discussed in this Article, nuclear power plants, frequently becomes obsolete. See, e.g., Stephen Maloney, PLEX: Nuclear Plant Life Extension or Extinction?, PUB. UtiL. FoRT., Nov. 15, 1992, at 15, 19-20 (discussing SONGS 1, a nuclear power plant originally built in 1967 that has since become obsolete). 
assets have some remaining life and have the capacity to generate a prospective stream of benefits. ${ }^{100}$ Switching costs are never zero, so redeployment will always be costly. ${ }^{101}$ A normal economy will thus always generate some resistance to policy change. But the problem identified in this Article is that legal rules have biased capital decisions toward larger capital, larger profits, and concomitantly larger risks of obsolescence. Having sunk a larger investment into capital, owners of that capital will resist policy reform with greater effort. A systemic overpromotion and overprotection of capital is thus creating a greater drag on policy reform than would otherwise be the case. ${ }^{102}$

\section{THE ROLE OF LAW AND LAWMAKING IN PROMOTING AND PROTECTING CAPITAL}

What exactly is the role of law in this story of policy inertia? The focus of this Article is on the role that law and policy play on the antecedent conditions that give rise to an overcapitalized economy, thereby generating policy inertia. Law and policy create overcapitalized economies in two ways: (i) laws that overpromote the formation of capital, and (ii) rules that overprotect capital from changes in its legal or economic environment.

Laws that promote the formation of capital create policy inertia indirectly because they lower the cost of capital and induce larger investments than would otherwise occur. ${ }^{103}$ Capital-friendly rules thus enlarge capital stock and therefore increase the incentives to resist reform. In short, capital-friendly rules impede policy reform by increasing the private costs of policy reform. ${ }^{104}$

100. See, e.g., Robertson, supra note 81, at 168 (noting that existing capital may pose barriers to reform when legislators conclude that it is more economically efficient to allow existing facilities to operate under less stringent (but environmentally harmful) standards and take advantage of their remaining capital rather than render them obsolete).

101. See Mark R. Patterson, Product Definition, Product Information, and Market Power: Kodak in Perspective, 73 N.C. L. REV. 185, 199 (1994) ("[E]very purchaser of a product that requires some capital investment incurs [switching costs]. Whenever such a product still has useful life, that remaining life will have value that will be costly to sacrifice in switching to a different product.").

102. Grandfather clauses "place[] the cost of the compliance burden on ... those who may not be aware that they will be affected, and therefore cannot combat the regulatory enactment." Robertson, supra note 81 , at 169 . This has the effect of preventing policy reform, as "legislators may be able to enact legislation which, without the inclusion of a protective grandfather clause, would be politically impossible." Id.

103. See, e.g., Ellen Lapson \& Richard Hunter, The Future of Fuel Diversity: Crisis or Euphoria?, PUB. UTIL. FORT., Oct. 2004, at 60, 64 (explaining how, through legislation, Congress can "reduce risk and lower the cost of capital").

104. See supra Part III.A (explaining how overcapitalization impedes environmental reform). 
The latter mechanism, rules that overprotect capital, prolong the life of capital even when environmental harms outweigh economic benefits. ${ }^{105}$ For instance, a rule grandfathering existing capital into older, less stringent regulatory schemes is one example. ${ }^{106}$ Note that this latter mechanism has a doubly pernicious effect: it entrenches existing capital regardless of its inherent social value, and it also produces an antecedent effect of providing assurances to new capital investors that their capital will also be similarly protected from unfavorable changes in legal rules. ${ }^{107}$ Investors will overinvest knowing that legal leniencies will at least partially insure them against obsolescence.

It is worth bearing in mind that the incentives for capital formation can be quite small. ${ }^{108}$ All that is needed is something to change the decision environment, not finance the undertaking. A small subsidy can induce the formation of capital by just tilting a close decision. It can also induce an upgrade in capital in a situation where a more modest investment would otherwise be privately optimal.

This Article will discuss five ways in which law and policy overpromote the formation of capital, and overprotect obsolescent capital: (1) tax benefits for energy industries; (2) tax benefits for mining industries; (3) electric utility regulation; (4) grandfathering; and (5) regulatory takings jurisprudence. This Part will also discuss the special political application of this theory to human and social capital.

\section{A. Tax Benefits for Energy Industries}

Clearly, federal and state governments have subsidized the formation of energy capital through tax benefits for a long time (by some estimates, a century). ${ }^{109}$ Equally clearly, subsidies have

105. See, e.g., Robertson, supra note 81, at 168-70 (asserting that laws, such as "grandfather clauses," have overprotected capital at the expense of environmental harm).

106. See id. at 168 ("[Grandfather clauses] allow some existing facilities to operate under less stringent standards.”).

107. Id. at 168-70 (describing the "perverse" effects of grandfather clauses).

108. See, e.g., Cont'l Tel. Co. of Pa. v. Pa. Pub. Util. Comm'n, 548 A.2d 344, 346 (Pa. Commw. Ct. 1988) (recalling that merely normalizing deferred tax expenses for a utility was designed to "provide incentives for capital formation"); see also infra Part III.B (setting forth a simple model showing that small incentives can lead to large increases in capital investment).

109. The expensing of intangible drilling and exploration costs for independent oil and gas producers has been allowed since 1913. ROBERT PIROG, CONG. RESEARCH SERV., R42374, OIL AND Natural Gas Industry TaX Issues IN the FY2013 Budget Proposal 3 (2012) [hereinafter CRS REPORT], available at http://budget.house.gov/uploadedfiles/crsr42374.pdf; see 26 U.S.C. § 263(c) (2012) (current tax code provision allowing such expensing). 
resulted in the formation of excess energy capital. ${ }^{110}$ But defining a subsidy is tricky, especially in the energy industry, in which there are both economies and diseconomies of scale, and sometimes the need for a regulated monopoly. Is the regulation and price-setting of electricity an energy subsidy? Also, certain tax advantages inure to the benefit of many industries, of which energy is just one; ${ }^{111}$ would that be an energy subsidy? The definitional problems abound.

This Article will focus on subsidies that: (i) involve direct payments from the federal government to an energy firm, (ii) reduce or defer the tax liability for an energy firm but do not apply to nonenergy firms, or (iii) provide some indirect but clearly financial benefit, such as a loan guarantee. These are the types of subsidies that are most likely to lower the cost of capital and induce excess formation of capital. ${ }^{112}$

Some subsidies may promote the formation of capital that confers positive externalities. For example, subsidizing the construction of electricity transmission lines is more akin to the provision of a public good ${ }^{113}$ that might warrant subsidization. In such cases, it might be hard to say if the capital being formed is "excess," as the public-good nature of the problem suggests that there would typically be a shortage of capital. ${ }^{114}$ Those subsidies are generally not targeted in this Article, and in fact, are considered below as the kind of subsidy that might be socially beneficial.

What is very much the target of this Article is the kind of energy subsidy that seeks to simply lower the price of energy.

110. See James C. Cox \& Arthur W. Wright, The Cost-Effectiveness of Federal Tax Subsidies for Petroleum Reserves: Some Empirical Results and Their Implications, in StUdies IN ENERGY TAX POLICY 177, 188 (Gerard Brannon ed., 1975) (finding that special tax provisions induced the petroleum industry to maintain larger investments in proven reserves); Walter J. Mead, The Performance of Government in Energy Regulations, 69 AM. ECON. REV. (PAPERS \& PROC.) 352, 352 (1979) ("These tax subsidies [in the form of percentage depletion allowance and expensing of intangible drilling costs] led to increased capital flows into exploration.").

111. See, e.g., Philip E. Harris, The Domestic Production Activities Deduction, 12 DRAKE J. AGRIC. L. 101, 103 (2007) (referencing Internal Revenue Code $§ 199$ regarding the Domestic Production Activities Deduction, which permits a taxpayer to deduct a percentage of their income produced through domestic production activities, regardless of industry).

112. See Erik F. Gerding, Deregulation Pas De Deux: Dual Regulatory Classes of Financial Institutions and the Path to Financial Crisis in Sweden and the United States, 15 NEXUS 135, 144-45 (2010) (noting that subsidies may afford lower cost of capital).

113. Tom Tietenberg \& Lynne Lewis, EnVironmental and Natural Resource ECONOMICS 31 (9th ed. 2012); Michael H. Dworkin \& Rachel Aslin Goldwasser, Ensuring Consideration of the Public Interest in the Governance and Accountability of Regional Transmission Organizations, 28 ENERGY L.J. 543, 559 (2007).

114. See discussion infra Part V (noting the necessity of adequate electric transmission capabilities). 
While low energy prices do stimulate economic development, there is no reason to believe that energy would be undersupplied absent a subsidy. ${ }^{115}$ Energy is not a public good. ${ }^{116}$

What then, are the subsidies that have led to the formation of excess energy capital? The coal industry has long enjoyed a privileged place in American energy policy. ${ }^{117}$ Most coal has been combusted for electricity generation, which, because it has predominantly been a regulated utility, has enjoyed a special set of legal protections that have resulted in a vastly overcapitalized industry. ${ }^{118}$ But mining coal itself is also a privileged activity. Coal mining rights are often owned and leased, and disposition of the coal typically results in a royalty payment. ${ }^{119}$ For individual owners receiving royalty payments, the royalty payments can be taxed at the lower capital gains tax rate. ${ }^{120}$ While ordinary lease payments (such as for residential or commercial property) must be taxed as income, ${ }^{121}$ coal mining rights are considered a capital asset that can be taxed at the lower rate. ${ }^{122}$ This brings marginal coal mines into production and expands the attendant infrastructure to extract and transport the coal.

115. See, e.g., Earl Blumenauer, Introduction, 15 LeWIS \& ClaRK L. REV. 315, 319 (2011) (noting that, while some emerging energy technologies may benefit from subsidies, traditional energy subsidies do not affect energy price or supply).

116. Note that this is not the same thing as making the argument that failing to internalize environmental externalities is tantamount to a subsidy. The policy remedy of an environmental externality is the imposition of a Pigouvian tax, not the withdrawal of a subsidy. Kyle D. Logue \& Joel Slemrod, Of Coase, Calabresi, and Optimal Tax Liability, 63 TAX L. REV. 797, 829 (2010) (defining a Pigouvian tax as one "designed to correct externalities"). The thrust of this Article is that certain legal institutions have created antecedent conditions that overpromote capital and once formed, overprotect. It is different to say that an omission such as the failure to impose a Pigouvian tax is part of that legal infatuation with capital.

117. FREESE, supra note 23, at 130 ("In the United States, though, still in its formative stages, coal would have an even greater impact on the political power structure of the nation [as compared to Britain].").

118. Peter S. Glaser, F. William Brownell \& Victor E. Schwartz, Managing Coal: How to Achieve Reasonable Risk with an Essential Resource, 13 VT. J. EnVTL. L. 177, 186 (2011); infra Part IV.C.

119. See, e.g., Willits v. Peabody Coal Co., 332 S.W.3d 260, 261-62 (Mo. Ct. App. 2010) (involving a situation in which coal mining rights were leased with an agreement to pay royalties upon the gross realization of the coal mined); Sam P. Burchett, The Applicant Violator System in Transition, 21 N. Ky. L. REV. 555, 559 (1994) (discussing the structure of the lessor-lessee relationship in coal mining leases).

120. 26 U.S.C. $\S 631$ (c) (2012). Section 631 also applies to timber and iron ore. Id. $\S 631(\mathrm{~b})-(\mathrm{c})$.

121. Id. $\S \S 1(\mathrm{c}), 61(\mathrm{a})(3),(6), 63(\mathrm{a})$ (including royalty payments and monies from property dealings in "gross income" and therefore in "taxable income," which is taxed at ordinary tax rates).

122. Id. §631(c). 
The other fossil fuels, oil and natural gas, have also been heavily subsidized. The Internal Revenue Code has long granted preferential tax treatment to entities undertaking capital projects for the exploration and extraction of oil and natural gas. ${ }^{123}$ Independent oil and gas producers-i.e., small, nonintegrated oil and gas producers ${ }^{124}$-are permitted to deduct from income taxes a "percentage depletion" of their oil or gas deposit basis rather than a cost depletion method of accounting. ${ }^{125}$ That is, rather than try to estimate the value of their deposit and deduct from their annual income taxes, they may simply deduct fifteen percent of their gross income as a generous proxy for the depreciated value of their oil and gas deposits. ${ }^{126}$ So long as the expected life of the oil and gas well is greater than 6.67 years $(100 \div 15)$, this represents an accelerated depreciation of their asset, and a financial benefit in the form of a deferred tax liability. ${ }^{127}$ In addition, independent producers are permitted to take a more generous deduction for "intangible drilling costs," generally defined as a cost that has no salvage value and is "incident[al] to and necessary for the drilling of wells and the preparation of wells for the production of oil and gas."128 These expenses expressly include "wages, fuel, repairs, hauling, supplies, etc.," that are required for the site preparation and drilling of wells. ${ }^{129}$ Seventy percent of intangible drilling costs are deductible from income in the year in which they are incurred, and the remaining thirty percent depreciated over a five-year period. ${ }^{130}$ This, too, represents a significant benefit in the form of a deferred tax liability. Finally, geological and geophysical exploration activities may be depreciated over an accelerated two-year schedule, again producing a frontloaded depreciation schedule and an effective

\footnotetext{
123. See, e.g., id. § 263(c) (allowing expensing of intangible drilling and exploration costs for independent oil and gas producers); CRS REPORT, supra note 109, at 3 ("The expensing of intangible drilling costs has been part of the federal tax code since 1913.”).

124. The Internal Revenue Code defines oil and gas producers as independent if, among other requirements, they have no more than $\$ 5$ million in gross receipts in a given year. 26 U.S.C. $§ 613 \mathrm{~A}(\mathrm{~d})(2)$.

125. Id. $\S 613 \mathrm{~A}(\mathrm{c})-(\mathrm{d})$; Treas. Reg. $\S 1.612-4$ (2013); CRS REPORT, supra note 109, at

126. CRS REPORT, supra note 109, at 5 .

127. Id.

128. 26 U.S.C. $§ 263(c)$; Treas. Reg. § 1.612-4; CRS REPORT, supra note 109, at 1; John S. Lowe, Analyzing Oil and Gas Farmout Agreements, 41 Sw. L.J. 759, 766 (1987) (internal quotation marks omitted).

129. Treas. Reg. § 1.612-4(a)-(b).

130. CRS REPORT, supra note 109, at 3.
} 5 . 
tax liability deferral. ${ }^{131}$ These three subsidies are, according to a 2011 report by the U.S. Energy Information Administration, three of the most valuable subsidies for the oil and gas industry, estimated by the EIA to be $\$ 980$ million, $\$ 400$ million, and $\$ 150$ million, respectively, for 2010 , for a total of about $\$ 1.53$ billion. ${ }^{132}$ Over time, the subsidies appear even more generous. A literature-based study done by a venture capital firm specializing in energy investments estimates that from 1918 to 2009, oil and gas firms have received $\$ 447$ billion in subsidies, measured in 2010 dollars. ${ }^{133}$

It is difficult to even guess at the effect of this infusion of money on capital formation in the energy industry, and on policy resistance. Studies have clearly shown a higher level of investment induced by these tax benefits. ${ }^{134}$ It is another matter to determine exactly how much these subsidies have bloated the capital stock. But $\$ 447$ billion over 91 years-an average of $\$ 4.9$ billion per year-is a lot of money to inject into even the mammoth oil and gas industries.

It is worth remembering two things. First, because a subsidy need only subtly nudge capital decisions, the capital-bloating

131. See id. at 6 (noting that the current law permits independent producers to depreciate geological and geophysical costs over a period of only two years).

132. U.S. ENERGy INFO. ADMIN., U.S. DEP'T OF ENERgY, DiRECT FINANCIAL INTERVENTIONS AND SUBSIDIES IN ENERGY IN FISCAL YEAR 2010, at 18 tbl.6 (2011) [hereinafter EIA 2010 REPORT], available at http://www.eia.gov/analysis/requests/ subsidy/pdf/subsidy.pdf. It is well worth noting that estimates of the value of these subsidies, as well as others, vary greatly. In recent budget negotiations, President Obama proposed a budget for 2013 that would have eliminated the percentage depletion allowance and the expensing of intangible drilling costs, and lengthened the two-year amortization period for geological and geophysical activities. CRS REPORT, supra note 109, at 1-2 \& tbl.1. The Congressional Research Service estimated the cost savings of these changes to be $\$ 13.9$ billion, $\$ 11.5$ billion, and $\$ 1.4$ billion, all over ten years. $I d$. at $5-7$.

133. See NANCy Pfund \& Ben Healey, DBL Investors, What Would JefFerson Do? The Historical Role of Federal Subsidies in Shaping America's Energy FUTURE 29 (2011), available at http://i.bnet.com/blogs/dbl_energy_subsidies_paper.pdf.

134. See, e.g., Cox \& Wright, supra note 110, at 188-89 ("Federal tax provisions for petroleum have had a statistically significant effect in increasing investment in petroleum reserves."); Mead, supra note 110, at 352 (reporting how certain tax subsidies "led to increased capital flows into [oil and gas] exploration"). According to the trade group Texas Alliance of Energy Producers, President Obama's similar proposal for fiscal year 2011 to eliminate these four tax benefits (and some other, much less expensive ones) would have reduced oil and gas investment by $\$ 26$ billion over ten years. TEXAS ALLIANCE OF ENERGY Producers, Oil \& Gas Provisions in President Obama's Proposed 2011 Budget (on file with Houston Law Review). But there is no study or data to support these estimates. Also, given the similarity of this figure with the other estimates (that of the CRS estimates for the President's 2013 proposal, CRS REPORT, supra note 109, and the EIA estimates of the cost for fiscal years 2007 and 2010, EIA 2010 REPORT, supra note 132, at 18 tbl.6, these estimates are more likely just the group's own estimates of the value of the withdrawn subsidies, not the absolute amount of withdrawn capital investments. 
effect of a subsidy could vastly exceed the cost of the subsidy. So $\$ 4.9$ billion could well have generated excess capital in an amount much greater than $\$ 4.9$ billion. Second, the subsidy itself is a source of funding for resistance to policy reform. If even a small fraction of $\$ 4.9$ billion were spent on litigation and lobbying activities, the effect on public policy would have been profound.

President Obama has repeatedly proposed to phase out or eliminate subsidies for oil and gas companies. ${ }^{135}$ To the extent that these subsidies stimulate the formation of capital, these are good steps. There is in most cases nothing remotely resembling a public good in the oil and gas industry warranting subsidization. But the mistake that the Obama Administration makes-like all preceding modern administrations - is to try to right a wrong by subsidizing competing, cleaner energy sources such as renewable energy. ${ }^{136}$ Because renewable energy does not impose the negative environmental externalities imposed by the extraction and combustion of fossil fuels, it would seem to stand to reason that it is worth subsidizing their production so as to place fossil fuels and renewable sources on a level playing field.

With an exception discussed below, ${ }^{137}$ this is mistaken thinking. A subsidy lowers the effective cost of capital and promotes the formation of new capital.138 The problem with promoting capital investment in nonfossil fuel energy sources is that it fails to learn from our past mistakes in promoting fossil fuel energy sources. How do we know this is the "right" energy technology? What will happen if information emerges pointing to

135. See Office of Mgmt. \& Budget, Exec. Office of the President, Budget of THE U.S. GOVERNMENT: FISCAL YEAR 2011, at 161-62 tbl.S-8, available at http://www.gpo.gov/fdsys/pkg/BUDGET-2011-BUD/pdf/BUDGET-2011-BUD.pdf (showing the budgetary plan to phase out fossil fuel tax preferences); OFFICE OF MGMT. \& BUDGET,

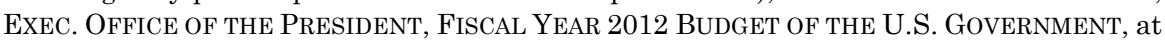
185-86 tbl.S-8, available at http://www.whitehouse.gov/sites/default/files/omb/budget/ fy2012/assets/budget.pdf (same); OfFICE OF MGMT. \& BUdGET, ExeC. OfFice OF THE President, Fiscal Year 2013 Budget of the U.S. Government, at 221-22 tbl.S-9, available at http://www.whitehouse.gov/sites/default/files/omb/budget/fy2013/assets/ budget.pdf (same).

136. See, e.g., Paul M. Kiernan et al., International Energy and Natural Resources, 44 INT'L LAW. 367, 375-76 (2010) (discussing the Obama Administration's support for renewable energy); Report of the Renewable Energy and Demand-side Management Committee, 30 ENERGY L.J. 273, 273-74 (2009) (discussing the Energy Improvement and Extension Act of 2008, signed into law by President George W. Bush).

137. See infra Part IV.B (discussing tax benefits for the mining industry).

138. See, e.g., Note, Reassessing Rent Control: Its Economic Impact in a Gentrifying Housing Market, 101 HARV. L. REV. 1835, 1847 (1988) (contending that government subsidies lower the effective cost of capital activities, such as low income house construction). 
alternative energy sources that are even cleaner? Promoting the formation of capital in specific renewable energy technologies runs the risk of locking in these technologies for longer than would be optimal. ${ }^{139}$ Future policy reform efforts to usher in newer and even better technologies will be met with resistance by the owners of this capital.

Energy policies in pursuit of cleaner alternatives to fossil fuel combustion are pursuing this misguided course. Federal energy subsidies have increased since 2007, and although they seek to correct a historical imbalance between fossil fuel and renewable energy technologies, ${ }^{140}$ they repeat the historical mistake of trying to accomplish an objective by exhorting the formation of capital. Federal energy subsidies more than doubled from 2007 to 2010, from almost $\$ 18$ billion to more than $\$ 37$ billion, and nearly all of that increase has been due to subsidies for nonfossil energy sources. ${ }^{141}$

In some aspects, new subsidies for renewable energy providers are even more capital-intensive than those for oil and gas. Producers of electricity from renewable energy sources have long benefited from a production tax credit, a unitary subsidy for each kilowatt-hour of electricity produced using a "qualified" production method. ${ }^{142}$ Section 1102 of the American Recovery and Reinvestment Act of 2009 (ARRA) sweetens things, allowing renewable energy providers to elect to take an Investment Tax Credit instead of the production tax credit, thereby frontloading the subsidy and immediately reducing the cost of capital, rather than allowing for a potentially larger stream of subsidy payments. ${ }^{143}$ But even better still, for certain renewable energy providers, ${ }^{144}$ Section 1603 of the ARRA offers a cash grant of ten or thirty percent in lieu of the investment tax credit and the production tax credit, ${ }^{145}$ the

139. See Nina Robertson, Bruce Rich \& Lynsey Gaudioso, As the World Burns: A Critique of the World Bank Group's Energy Strategy, 43 ENVTL. L. REP. 10,760, 10,768 (2013) ("Every new fossil fuel investment locks in [the technology] for decades.").

140. PFUnD \& HEALEY, supra note 133, at 29 (showing a substantial imbalance among the cumulative historical subsidies for oil and gas, nuclear energy, biofuels, and renewable energy sources).

141. EIA 2010 REPORT, supra note 132, at xi tbl.ES1.

142. 26 U.S.C. $\S 45($ a) (2012).

143. American Recovery and Reinvestment Act of 2009 (ARRA), Pub. L. No. 111-5, $\S 1102$, 123 Stat. 115, 319-20 (as amended by the Tax Relief, Unemployment Insurance Reauthorization, and Job Creation Act of 2010, Pub. L. No. 111-312, § 707, 124 Stat. 3296, 3312).

144. Solar, landfill gas, trash, geothermal, wind, hydro, biomass, marine and hydrokinetic energy sources qualify. ARRA $\S 1603(d)(1)$ (citing 26 U.S.C. $\S 45(d)(1)-(4)$, (6)-(7), (9), (11)).

145. Id. $\S 1603(\mathrm{a})-(\mathrm{b})$. 
advantage over a tax credit being that there need not be any income against which to offset a tax credit. ${ }^{146}$ The Section 1603 program has been "enormously popular," with expenditures for the grant totaling $\$ 4.2$ billion in $2010,{ }^{147}$ and far surpassing the costs of the production tax credit and the investment tax credit, which were $\$ 1.5$ billion and $\$ 130$ million, respectively, in $2010 .{ }^{148}$ It was even an explicit goal of ARRA to inject money into the economy to assist in the economic recovery. ${ }^{149}$

In addition, the Department of Energy (DOE) operates several loan guarantee programs for qualifying projects or firms. Section 406 of the ARRA, amending Title XVII of the Energy Policy Act of 2005, provides for loan guarantees for "[r]enewable energy systems," "[e]lectric power transmission systems," and "[1]eading-edge biofuel projects." 150 By the end of 2010, DOE had issued over $\$ 25$ billion in loan guarantees. ${ }^{151}$ It was under this program that DOE issued a loan guarantee to the failed solar energy company, Solyndra, which brought controversy to the program. ${ }^{152}$ Adding to the controversy, DOE is authorized to guarantee $100 \%$ of a loan, not a more traditional fraction, like eighty percent. ${ }^{153}$ Some funding was also issued to aid in the construction of nuclear power plants. ${ }^{154}$ Overall, spending on renewable energy technologies was much greater than spending on fossil fuel technologies: more than $\$ 14$ billion to just over $\$ 4$ billion. ${ }^{155}$

146. See John A. Herrick \& Cara S. Elias, Federal Incentives for Clean Energy After Solyndra: A Post-Recovery Act Precipice, 87 N.D. L. REV. 625, 678 (2011) ("By allowing renewable energy investors to monetize the related tax credits, it has created an avenue for investment in projects that would otherwise have been blocked during the economic lull following the Recovery Act due to the dearth of investors with tax liability for the tax credits to offset.").

147. EIA 2010 REPORT, supra note 132, at 30.

148. Id. at 13 tbl.3.

149. ARRA $\S 3(\mathrm{a})(1)$.

150. Id. $\S 406$.

151. EIA 2010 REPORT, supra note 132, at 59.

152. See, e.g., Hilary Kao, Beyond Solyndra: Examining the Department of Energy's Loan Guarantee Program, 37 WM. \& MARY ENVTL. L. \& POL’Y REV. 425, 475-78 (2013) (describing the controversy surrounding the loan guarantee program after "Solyndra experienced financial difficulties despite having received the DOE loan guarantee commitment"); Ashley Southall, House Passes Solyndra Act Aimed at Obama, CAUCUS (Sept. 14, 2012, 5:46 PM), http://thecaucus.blogs.nytimes.com/2012/09/14/house-passessolyndra-act-aimed-at-obama/?ref=solyndra\&_r=0.

153. See EIA 2010 REPORT, supra note 132, at 64 (explaining that, initially, DOE could guarantee a more traditional eighty percent of a loan, but by the time the final rulemaking was passed, DOE was authorized to guarantee the full amount).

154. See id. (describing how, with the passage of the Fiscal Year 2008 Appropriations Act, DOE was authorized to allocate $\$ 18.5$ billion in loan guarantees to nuclear plants).

155. Id. at xiii tbl.ES2. 
The goal of trying to rapidly ramp up renewable energy production is certainly laudable, especially in the face of an inability to pass comprehensive climate legislation that might achieve an energy transition in a more holistic way. ${ }^{156}$ It is still troubling, however, to consider how much capital is being formed, with relatively little known about the relative merits of wind energy as opposed to other technologies that may emerge in the next several years. From 2000 to 2010, net generation of electricity from wind power rose from 6 billion kilowatt-hours to 95 billion, ${ }^{157}$ and net summer capacity for wind energy grew from just about 8 gigawatts in 2005 to over 39 gigawatts in 2010.158 This is troubling because the technology of electricity production is constantly evolving. Only recently did Congress suddenly notice the potential of hydrokinetic energy, the use of wave action to generate electricity. ${ }^{159}$ Only recently has low-tech solar thermal energy gained attention, ${ }^{160}$ as it has become competitive much more quickly than the previously favored solar technology, photovoltaics. ${ }^{161}$ If a new and better renewable energy technology is discovered, what will be the policy response of wind energy developers that have invested billions of dollars?

As I have argued elsewhere, the correct response to the environmental externality of emissions from fossil fuel-fired sources is not to try to subsidize all that is not fossil fuels. ${ }^{162}$ If there is a negative environmental externality, the right approach is to tax the negative externality, not to subsidize everything else. It seems politically more palatable to

156. Hari M. Osofsky, Diagonal Federalism and Climate Change Implications for the Obama Administration, 62 ALA. L. REv. 237, 296 (2011) ("Congress has failed to pass major climate change legislation ....”).

157. EIA 2010 REPORT, supra note 132, at xx tbl.ES5.

158. U.S. ENERgy Info. Admin., U.S. DeP'T OF ENERgy, EleCtric Power ANNUAL 2010, at 6 tbl.1.1B (2011), available at http://www.eia.gov/electricity/annual/html/table1. 1b.cfm.

159. FERC Issues First Pilot License for Tidal Power Project in New York, FED. ENERGY REGULATORY COMM'N, http://www.ferc.gov/media/news-releases/2012/2012-1/0123-12.asp (last updated Jan. 23, 2012) (illustrating that hydrokinetic projects are a recent endeavor); Hydrokinetic Projects, FED. ENERGy REGULATORY COMM’N, http://www.ferc.gov/ industries/hydropower/gen-info/licensing/hydrokinetics.asp (last updated Jan. 22, 2014).

160. U.S. ENERGY INFO. ADMIN., supra note 158, at 6 tbl.1.1.B (showing a steady increase in net capacity of solar thermal energy from 2000 to 2010); S. Mekhilef, R. Saidur \& A. Safari, A Review on Solar Energy Use in Industries, 15 Renewable \& Sustainable ENERGY REVIEWS 1777, 1778-79 (2011), available at http://www.sciencedirect.com/ science/article/pii/S1364032110004533\# ("Due to the global energy shortage and controlling harmful environmental impacts, application of solar energy has [been] receiving much attention in the engineering sciences.").

161. HsU, supra note 7, at 43.

162. See id. at 36-37 ("Government subsidization should be viewed with skepticism, rather than being the presumptive first option.”). 
subsidize "good" industries than it is to tax "bad" industries, 163 but the politically expedient approach is less efficient. ${ }^{164}$ In the context of energy policy, a much more effective and efficient policy tool than subsidization is a carbon tax. ${ }^{165}$ Among other problems with the pushing-on-a-string effectiveness of trying to prop up all that is putatively good, ${ }^{166}$ subsidizing "good" industries promotes the excessive formation of capital. A tax on a negative environmental externality is capital neutral. ${ }^{167}$ Capital formed in one industry (e.g., wind energy) because negative externalities are taxed in another industry (coal, oil, or natural gas) will not be as likely to become obsolete because it is responding to a technology-neutral price signal, not a political judgment.

\section{B. Tax Benefits for Mining Industries}

There is one industry that may benefit from even greater taxpayer generosity than the energy sector: the hard rock mining industry. Few industries create as many or as severe environmental externalities as the mining industry. ${ }^{168}$ But apparently following in the same industrial-development, lowcommodity-price rationales that animate energy subsidies, a variety of favorable tax provisions facilitate the formation of

163. See id. at 118-23 ("[P]ublic opinion polls seem to show that the American public strongly favors subsidy programs to reduce greenhouse gases but strongly opposes carbon taxes or gasoline taxes ....”).

164. See id. at 53-59 (critiquing the United States' track record with respect to making "strategic decisions" and commenting how it is "too easy and too dangerous to fall into the trap of thinking that governments can 'fix' the problem directly, funding a potential 'home run' or 'gamechanger"'); see also MCKinsey \& Co., PATHWAYs TO A LowCARBON ECONOMY 73 (2009), available at www.mckinsey.com/ /media/mckinsey/dotcom/ client_service/sustainability/cost curve pdfs/pathways_lowcarbon_economy_version2.ashx (illustrating how the use of subsidies can cause waste).

165. See HsU, supra note 7, at 34-37 (comparing the effects of taxing carbon versus subsidizing renewable energy); MCKINSEY \& Co, supra note 164, at 19, 73 (suggesting that a carbon tax would help reduce emissions and discussing the negative externalities of subsidies).

166. See HsU, supra note 7, at 34-37 (expressing some limitations of subsidization).

167. See id. at 45 (labeling a carbon tax as "capital-neutral" because it "does not encourage the formation of expensive physical capital that would inhibit future changes in production").

168. See, e.g., Principles for Responsible Investment, United Nations Env't Program, Universal OWNERship: Why EnVIRONMENTAL Externalities MATter to InSTITUTIONAL INVESTORS 27 fig.3 (2011), available at http://www.unpri.org/files/ uop_long_report.pdf (listing "Industrial Metals \& Mining" as the third-highest industry sector in terms of environmental costs); Emissions of Greenhouse Gases in the U.S., U.S. ENERgy INFo. AdMin., U.S. DeP’T OF EnERgY (Mar. 31, 2011), http://www.eia.gov/ environment/emissions/ghg_report/ghg_methane.cfm ("Natural gas systems and coal mines are the major sources of methane emissions in the energy sector." (citation omitted)). 
mining capital. Exploration and development expenses for mining companies, unlike for oil and gas companies, are deductible in full in the year those expenses are incurred.169 The deduction is required to be recaptured when the mine goes into production, but many miners are able to avoid this taxable event by avoiding "production" status. ${ }^{170}$

In Canada, where mining is a centrally important industry, ${ }^{171}$ small, start-up mining companies, known as "juniors," can pass through capital losses-losses that cannot be deducted from their income because juniors have no income-up to acquiring companies. ${ }^{172}$ The advantage of having this benefit of "flow-through" shares is that a tax deduction is essentially sold from an entity that has no income against which to deduct expenses, to a larger entity that does. Thus, the tax benefit is commodified and made into a valuable asset, creating a premium for shares of juniors and stripping away significant risk in an inherently risky business. From 1987 to 1991, $\$ 2.5$ billion (CAD) of flow-through shares were exchanged, accounting for sixty percent of the funding for mining exploration over that period. ${ }^{173}$ Empirical research suggests that this has led to capital overinvestment in the mining industry and below-market returns to mining capital. ${ }^{174}$ It was the stated policy of the Canadian government that the flow-through share device should promote equity investments in mining and petroleum companies in Canada, and it should provide financing assistance to junior,

169. Compare 26 U.S.C. $§ 617(a)(1)$ (2012), with 26 U.S.C. $§ 461(i)(2)$, and 26 U.S.C. $\S 263(\mathrm{a}),(\mathrm{c})$.

170. Treas. Reg. $\S 1.617-3$ (2013).

171. Mining, quarrying, and oil and gas extraction together represented eight percent of the Canadian economy, and roughly twenty-seven percent of the Canadian goods-producing economy in 2012. Canadian Industry Statistics: Gross Domestic Product (GDP): Canadian Economy (NAICS 11-91), INDUS. CAN., http://www.ic.gc.ca/eic/site/cissic.nsf/eng/h_00013.html\#vla2b (last updated Dec. 18, 2013).

172. Income Tax Act, R.S.C. 1985, c. L-1 $\S ~ 40(1)(b), ~ 44.1(8)(b), 110.6(2.1)(d)$ (Can. 5th Supp.); KPMG in Canada, KPMG, A Guide to Canadian Mining TaXation 7, 12 (Sept. 2011), http://www.kpmg.com/Ca/en/IssuesAndInsights/ArticlesPublications/Docu ments/5539_KPMG_A\%20Guide\%20to\%20Canadian\%20Mining\%20Taxation_web.pdf; see also Christopher Berry, How to Blow Up a Start Up-The Biggest Financing Pitfall for Entrepreneurs, FORBES (July 16, 2012), http://www.forbes.com/sites/discoveryinvesting/ 2012/07/16/how-to-blow-up-a-start-up-the-biggest-financing-pitfall-for-entrepreneurs-2/ (discussing how small start-up mining companies are known as juniors and "generate no cash flow, revenue, or earnings").

173. Gordon J. Lenjosek, A Canadian Tax Incentive for Equity Investments in Mining and Energy Companies, New DiRECTIONs For Evaluation, Fall 1998, at 117, 120.

174. See id. at 127 (reporting that "overheating" in the mining industry caused incremental drilling activity to be lower than incremental mining exploration spending). 
nontaxpaying, companies. ${ }^{175}$ It has apparently succeeded in this respect. ${ }^{176}$

The extraction of valuable deposits has obviously been vital in developing the economies of wealthy countries. ${ }^{177}$ These sectors are particularly capital-intensive and foundational in that their abundance seems to be a predicate to economic growth, so perhaps they are particularly tempting targets for subsidization. But this is precisely the superficial and specious growth paradigm that retards policy reform. It is unnecessary, and indeed potentially very harmful, for government policy to actively stimulate economic growth by promoting the formation of capital. The energy and hard rock mining industries stand as prominent examples of this bias.

\section{Electric Utility Regulation}

The law is perhaps no more obsessed with capital in any other area than it is in the area of regulated electric utilities. Regulated electric utilities are only permitted by their regulators to charge ratepayers in accordance with the general formula

$$
R=O+B \bullet r
$$

where $R$ is the total allowed revenues (to be divided up among ratepayers), $O$ is the allowed operating expenses, $B$ is the company's "rate base," all those capital assets from which the company is permitted to earn a return, and $r$ is the permitted rate of return. ${ }^{178}$ Given this regulatory structure, it is in the company's interest to acquire more capital and expand the rate base as much as possible in order to maximize their permitted revenues. This bias is commonly known as the "Averch-Johnson effect." ${ }^{179}$ Although additions to the company's rate base must be

\footnotetext{
175. Id. at 119 .

176. See id. at 125 ("[F]low-through shares raised a substantial amount of equity-based financing for exploration and development[,] ... were the dominant means by which funding was raised for mining exploration[,] resulted in significant incremental spending on mining and petroleum exploration and significant incremental exploration drilling activity[,] ... and assisted non-taxpaying junior exploration companies.").

177. See Mining, Minerals \& Sustainable Dev. Project, Int'L Inst. For Env't \& Dev., BREAKING NEW GROUND 172 (2002), http://pubs.iied.org/pdfs/G00900.pdf ("Many of the world's richest countries have benefited greatly from minerals extraction. Australia, Canada, Finland, Sweden, and the United States, for example, have all had extensive minerals industries and used them as a platform for broad-based industrial development.”).

178. Fred Bosselman, Jim Rossi \& Jacqueline Lang Weaver, Energy, Economics, AND THE ENVIRONMENT 507 (2000) (describing the formula).

179. Harvey Averch \& Leland L. Johnson, Behavior of the Firm Under Regulatory Constraint, 52 AM. ECON. REV. 1052, 1052-53 (1962).
} 
"prudently incurred,"180 and must be "used and useful,"181 the reality is that the company often has the upper hand in a ratemaking setting in which it seeks to justify its expenditures to a regulator. ${ }^{182}$ Empirical evidence for the Averch-Johnson effect is not unambiguous, but generally supportive. ${ }^{183}$

Courts and commissions hearing ratemaking cases do not, however, seem overly concerned about the Averch-Johnson effect. In In re Limerick Nuclear Generating Station, the Pennsylvania Public Utility Commission addressed the question of whether a project may be included in the utility's rate base if the project was prudent at the time of commencement but had subsequently become unnecessary. ${ }^{184}$ The opinion, one of only a few that actually considered and discussed the Averch-Johnson

180. Duquesne Light Co. v Barasch, 488 U.S. 299, 309 (1989) ("Under the prudent investment rule, the utility is compensated for all prudent investments at their actual cost when made (their "historical" cost), irrespective of whether individual investments are deemed necessary or beneficial in hindsight."); Fed. Power Comm'n v. Hope Natural Gas Co., 320 U.S. 591, 600 (1944) (discussing the Natural Gas Act's requirement that all natural gas rates be just and reasonable); Pa. Pub. Util. Comm'n v. Phila. Elec. Co., 31 P.U.R.4th 15, 29 (Pa. P.U.C. 1978) (entering judgment against a utilities company because of expenditures "which would not have been made had prudent management been exercised"); Richard A. Posner, Natural Monopoly and Its Regulation, 21 STAN. L. REV. 548, 592, 617 (1969) (describing the basic workings of the regulatory process).

181. Barasch, 488 U.S. at 303-04; Bill Clinton et al., FERC, State Regulators, and Public Utilities: A Tilted Balance?, NAT. Resources \& ENV'T, Spring 1987, at 11, 11, 43 (describing the "used and useful" requirement).

182. For a discussion of the administrative law surrounding ratemaking cases, see Jacqueline Lang Weaver, Can Energy Markets be Trusted? The Effect of the Rise and Fall of Enron on Energy Markets, 4 Hous. Bus. \& TAX L.J. 1, 13, 15 (2004), and Jim Rossi, The Political Economy of Energy and Its Implications for Climate Change Legislation, 84 TUL. L. REV. 379, 383, 391, 393 (2009). In In re Limerick Nuclear Generating Station, the Pennsylvania Utilities Commission, in evaluating expert testimony on a variety of technical and economic matters, wrote:

In performing our analysis, we are cognizant of the fact that many of the calculations and figures presented in the context of this proceeding are somewhat speculative. Although no one can perfectly see the future, we are convinced that those estimates represent more than educated guesswork on the part of the witnesses.

In re Limerick Nuclear Generating Station, 48 P.U.R.4th 190, 192 (Pa. P.U.C. 1982); see also Posner, supra note 180, at 617 (showing that, in practice, the regulatory agencies do not have as much power over ratemaking as they do in theory).

183. See, e.g., Léon Courville, Regulation and Efficiency in the Electric Utility Industry, 5 BELL J. ECON. \& MGMT. SCI. 53, 70 (1974) (confirming the Averch-Johnson proposition of inefficiency); H. Craig Peterson, An Empirical Test of Regulatory Effects, 6 BELL J. ECON. \& MGMT. SCI. 111, 112, 119, 124 (1975) (providing empirical evidence to support the Averch-Johnson proposition); Robert M. Spann, Rate of Return Regulation and Efficiency in Production: An Empirical Test of the Averch-Johnson Thesis, 5 BELL J. ECON. \& MGMT. SCI. 38, 49-50 (1974) (demonstrating the soundness of the AverchJohnson proposition through a trans-log production function).

184. In re Limerick Nuclear Generating Station, 48 P.U.R.4th, at 200-01. 
effect, minimized its import. ${ }^{185}$ The Commission's glib dismissal of the Averch-Johnson effect reveals the bias of ratemaking bodies:

We could better spend our time focusing on whether undue and unnecessary financial constraints are leading us toward a future of insufficient electricity supply and the attendant problems of unnecessarily high electricity prices, unnecessarily high oil consumption, and reduced economic growth. These questions transcend the close-in arguments on [construction work in progress] that turn on relatively technical points of consumer discount rates and impacts on cost of capital. 186

This treatment seems to acknowledge that the AverchJohnson effect is a valid theoretical consideration, but not of any practical importance, at least relative to other considerations. That is regrettable, and it highlights how disinclined policymakers and lawmakers are to critically consider the true usefulness of hard and familiar capital. Utility commissions, it would seem, are still more concerned with low electricity prices and are willing to allow the construction of more capital to ensure them. ${ }^{187}$

Electric utility regulation also presents the most compelling illustration of how an industry will fight to maintain a privileged position: rent-preserving through resisting policy reform. The catchphrase "stranded costs" was born in the wake of widespread state efforts to deregulate electricity generation and liberalize energy markets. ${ }^{188}$ Liberalization means loss of monopoly power, and incumbent electricity generation firms in states trending towards deregulation complained loudly about the costs of power plants that had not yet been recouped from ratepayers. ${ }^{189}$ Estimates of the amount of money believed to be at stake in the

185. Id. at 211-12 ("Averch-Johnson phenomenon-This concept, developed in the early 1960 s, maintains that the utilities will invariably seek to overbuild their systems. The financial disincentive of not allowing [construction work in progress] in the rate base is seen as counteracting this tendency.... The Averch-Johnson phenomenon is no longer applicable-Even if it did apply in the early 1960s, there is little current credibility to the [Averch-Johnson] phenomenon given the current depressed financial condition of the industry.").

186. Id. at 212 .

187. Severin Borenstein, The Trouble with Electricity Markets: Understanding California's Restructuring Disaster, J. ECON. PERSP., Winter 2002, at 191, 192, 195 (illustrating this concern and its effects on the state of California).

188. Id. at 191, 193-94.

189. Mark Armstrong \& David E.M. Sappington, Regulation, Competition, and Liberalization, 44 J. ECON. LiTERATURE 325, 329-30 (2006); Timothy J. Brennan \& James Boyd, Stranded Costs, Takings, and the Law and Economics of Implicit Contracts, $11 \mathrm{~J}$. REG. ECON. 41, 42, 44-46, 50 (1997). 
mid-1990s, the height of deregulation speculation, ranged from $\$ 34$ billion to $\$ 210$ billion. ${ }^{190}$ As explained in this Article, ${ }^{191}$ the expected stream of benefits could well be greater than the value of the capital stock. The specter of deregulation, which would have disadvantaged incumbent electricity generators, was enough for the industry to embark upon a massive campaign for compensation. ${ }^{192}$

The campaigns surrounding electricity deregulation are complicated because electricity deregulation itself is complicated. States have traditionally regulated vertically integrated utilities, and as such, have had primary jurisdiction over electricity generation, transmission, distribution, and marketing. ${ }^{193}$ However, not only does the Federal Energy Regulatory Commission (FERC) regulate the interstate transmission of electricity, ${ }^{194}$ but the federal government has from time to time played a prominent role in setting electricity policy, such as when Congress passed the 1978 Public Utility Regulatory Policies Act (requiring utilities to buy power from cogeneration sources and from renewable energy sources) ${ }^{195}$ and the 1992 Energy Policy Act, amended in 2005 (which required FERC to order the opening of interstate transmission lines to independent generators), 196 and when FERC actually issued the order to unbundle electricity services $^{197}$ and open up interstate transmission lines under Order 888 (which also mandated other requirements of utilities and

190. Eric Hirst \& Lester Baxter, How Stranded Will Electric Utilities Be?, PuB. UTIL. FORT., Feb. 15, 1995, at 30, 31.

191. See supra Part III.B.

192. Reed W. Cearley \& Daniel H. Cole, Stranded Benefits Versus Stranded Costs in Utility Deregulation, in 7 The Economics of Legal Relationships: The End of A Natural Monopoly: Deregulation and Competition in the Electric Power INDUSTRY 169, 170-72, 179, 181-82, 184-85 (Peter Z. Grossman \& Daniel H. Cole eds., 2003).

193. Robert J. Michaels, Electricity and Its Regulation, LIBRARY ECON. \& LIBERTY (2008), http://www.econlib.org/library/Enc/ElectricityandItsRegulation.html.

194. What FERC Does, FED. ENERGY REgUlatory COMM'N, https://www.ferc.gov/about/ferc-does.asp (last updated May 28, 2013).

195. Public Utility Regulatory Policies Act of 1978, Pub. L. No. 95-617, § 210, 92 Stat. 3117, 3144 (codified as amended at 16 U.S.C. § 824a-3 (2012)).

196. Energy Policy Act of 1992, Pub. L. No. 102-486, §§ 721-722, 106 Stat. 2776, 2915-20 (codified as amended at 16 U.S.C. $\$ \S 824 j-824 \mathrm{k}$ ); Bob Eleff, Federal Regulation of Electric Transmission: From Monopolistic Barrier to Competitive Force, RESEARCH DEP'T, MinN. House OF REPRESENTATIVES 5 (Dec. 2012), available at http://www.house.leg.state. $\mathrm{mn} . \mathrm{us} / \mathrm{hrd} / \mathrm{pubs} /$ regelectric.pdf.

197. "Unbundling" means to break up the traditionally vertically integrated electric utilities typical of the regulated monopoly regime. See, e.g., Paul L. Joskow, California's Electricity Crisis, 17 OXFORD REv. ECON. POL'Y 365, 367 (2001) (distinguishing between "wholesale" and "unbundled" transmission service). 
transmission owners). ${ }^{198}$ Lobbying and lawsuits thus took place on both the state and federal levels.

The unusual characteristic of the electricity deregulation debate was that almost all of the parties, from integrated electric utilities, to consumer groups, to rural electric cooperatives, agreed: electricity deregulation could work, if done properly (their way). ${ }^{199}$ The disagreement was which path would be taken. Electric utilities spent $\$ 5.4$ million in 1992 campaign contributions, which increased to $\$ 9.5$ million in $1996 .{ }^{200}$ Interest groups self-reported a conservatively estimated total of $\$ 50$ million in contributions. ${ }^{201}$ The end result is a mixed bag: fifteen states, plus Washington, D.C., either fully deregulated or actively regulated their electricity markets, and seven have suspended their deregulation plans, ${ }^{202}$ including California, which suffered the most humiliating failures of deregulation. ${ }^{203}$ As of 2010, the remaining states were not in the process of deregulating electricity at all. ${ }^{204}$

Granted, electricity deregulation is complicated business, challenging the capacity of elected legislatures to comprehend. But given the consensus among interest groups that electricity deregulation is a good thing (as long as they get their way), the stalled nature of electricity deregulation serves as a testament to the power of incumbency. If there is any doubt as to the power of the electricity generation industry to get its way, more evidence can be found in the American Clean Energy and Security Act of 2009, also known as Waxman-Markey after its House sponsors. ${ }^{205}$ Waxman-Markey, which passed the U.S. House of Representatives in 2009, would have instituted a greenhouse gas

198. 18 C.F.R. $\S 35.28$ (2013).

199. Electricity Deregulation, OPENSECRETS, http://www.opensecrets.org/news/issues/ electricity/index.php (last visited Feb. 6, 2014).

200. Id.

201. Id.

202. U.S. EnERgy Info. Admin., U.S. DeP'T of EnERgy, Status of ElECTRICITy RESTRUCTURING BY STATE (Sept. 2010), available at http://www.eia.gov/cneaf/electricity/ page/restructuring/restructure_elect.html.

203. California electricity consumers suffered high prices and brownouts when electricity suppliers accumulated market power through failures of the deregulation plan and chose to withhold power in times of electricity shortages. See, e.g, Joskow, supra note 197, at 377-78, 384; Peter Navarro, On the Political Economy of Electricity DeregulationCalifornia Style, EleCtRICITy J., March 2004, at 47, 47-49, 53 (commenting on the "California electricity crisis" and the mistakes leading up to it).

204. U.S. ENERGY INFO. ADMIN., supra note 202.

205. American Clean Energy and Security Act of 2009, H.R. 2454, 111th Cong. (2009); HsU, supra note 7, at 120 (discussing how the Waxman-Markey Act "provided the disadvantaged coal industries and the utilities that burn coal with enormous payoffs in the form of free allowances"). 
cap-and-trade program, allocating permits to emit greenhouse gases, at least initially, by simply writing the allocations into the bill. ${ }^{206}$ The largest recipient of freely allocated emissions permits? Electric utilities would have received $43.75 \%$ of the freely allocated allowances for 2012 and 2013, declining gradually to $7 \%$ by $2029 .{ }^{207}$ It was no surprise that the bill had the support of the Edison Electric Institute, the trade association for electric utilities, because it was deeply involved in writing it. ${ }^{208}$

\section{Grandfathering}

Grandfathering, or more generally "transition relief," is a common practice in lawmaking, especially in environmental lawmaking. ${ }^{209}$ Because environmental regulation can severely affect the value of capital, environmental laws have often exempted existing capital from new laws or regulations. ${ }^{210}$ Lawmakers seem particularly worried about negative impacts on capital. ${ }^{211}$

The normative discussion on grandfathering has been largely efficiency-oriented, centering on a discussion of how to

\footnotetext{
206. American Clean Energy and Security Act of 2009, § 727.

207. Id. § 782(a).
}

208. EEI president Thomas Kuhn also made a number of post-passage efforts to support a Senate bill that would be compatible with the Waxman-Markey bill he helped craft. HsU, supra note 7, at 120 (illustrating the Edison Electric Institute's partnership in crafting the bill); John M. Broder, Senate Gets a Climate and Energy Bill, Modified by a Gulf Spill That Still Grows, N.Y. Times, May 13, 2010, at A18 ("The leader of the main utility industry trade group, Thomas R. Kuhn of the Edison Electric Institute, stood with Mr. Kerry and Mr. Lieberman on Wednesday and endorsed their bill.”).

209. Bruce R. Huber, Transition Policy in Environmental Law, 35 HARV. ENVTL. L. REV. 91, 92, 96 (2011) (noting that the distinction between new sources of pollution and existing sources "reflects a recurring political problem faced by makers of environmental policy"); Jonathan Remy Nash, Allocation and Uncertainty: Strategic Responses to Environmental Grandfathering, 36 ECOLOGY L.Q. 809, 811 (2009) ("[T]he government may choose to base allocations not on current activities, but on recent activities that predate the announced intention to implement limitations on resource access. Such systems have become increasingly common in the context of environmental and natural resource regulation.”); Jonathan Remy Nash \& Richard L. Revesz, Grandfathering and Environmental Regulation: The Law and Economics of New Source Review, 101 Nw. U. L. REV. 1677, 1680 (2007) ("The problem of whether and how to extend favorable treatment to existing sources is a recurring one in environmental law."); Robert N. Stavins, VintageDifferentiated Environmental Regulation, 25 STAN. ENVTL. L.J. 29, 34 (2006) ("[G]randfathering is likely to be a politically expedient option for legislators, since it allows leeway in rewarding firms and in distributing the costs and benefits of regulation among jurisdictions.”).

210. See Robertson, supra note 81, at 152, 157-58 (noting that environmental laws often contain grandfathering clauses which exempt existing capital from new regulations).

211. See, e.g., Huber, supra note 209, at 127 ("Both state and federal lawmakers have shied away from imposing the enormous costs associated with the mandatory retrofit, upgrade, or retirement of in-use diesel trucks ....”). 
allocate the "costs of legal transitions."212 Louis Kaplow's seminal An Economic Analysis of Legal Transitions argued against grandfathering on the grounds that legal transitions are not sufficiently different from other changes in the economic environment to warrant different treatment. ${ }^{213}$ One might argue that in legal changes, as in market changes, it is the private party that is better able to anticipate change. ${ }^{214}$ The more compelling arguments, however, point out how a regime of grandfathering creates perverse incentives. ${ }^{215}$ There is obviously the transition relief itself, which could become the subject of rentseeking. ${ }^{216}$ Also, regulatory targets might, in anticipation of transition relief, have less incentive to anticipate very foreseeable legal changes, for example, as a result of emerging public health or safety concerns. ${ }^{217}$ Additionally, in regimes in which transition relief might be pegged to historical baselines, just a whiff of new regulation may send regulatory targets off in a race to boost their baselines in the hopes of securing a larger share of the impending transition relief. ${ }^{218}$ And finally, policymakers have utterly failed to appreciate that grandfather status confers an asset in the form of a legal exemption, which competitors, but not incumbents, have to observe. ${ }^{219}$ This can be an enormous advantage, and a barrier to entry, as new entrants are required to spend hundreds of millions that incumbents do

212. See id. at 92 (suggesting that economists believe the crux of transition policy is efficiency); see also DANIEL SHAVIRo, WHEN RUlEs CHANGE: AN ECONOMIC AND POLITICAL ANALYSIS OF TRANSITION RELIEF AND RETROACTIVITY 221-23 (2000) (positing that delay is superior to grandfathering for transition relief); Louis Kaplow, An Economic Analysis of Legal Transitions, 99 HARV. L. REV. 509, 512, 584-87 (1986) (analyzing the undesirability of grandfathering).

213. Kaplow, supra note 212, at 513, 581-82 (1986) ("As an initial hypothesis, government transitions warrant the same treatment as market transitions: no transition relief.").

214. See Saul Levmore, Changes, Anticipations, and Reparations, 99 CoLUM. L. REV. 1657, 1662-65 (1999) (explaining the incentive private parties have to anticipate changes in the law).

215. See Maria Damon et al., Grandfathering 8, 10 (Ind. Univ. Sch. Pub. \& Envtl. Affairs, Research Paper No. 2012-11-03, 2012), available at http://ssrn.com/ abstract=2182573 (commenting on how grandfathering can "reduce economic efficiency and social welfare").

216. Levmore, supra note 214, at 1681-82, 1698.

217. Nash \& Revesz, supra note 209, at 1725.

218. See Nash, supra note 209, at 820, 822, 836-37 (discussing the negative impact that "first possession" can have on resources); see also Shi-Ling Hsu \& James E. Wilen, Ecosystem Management and the 1996 Sustainable Fisheries Act, 24 ECOLOGY L.Q. 799, 806-10 (1997) (describing how the fishing industry has responded to and evaded tight regulations).

219. Steven Shavell, On Optimal Legal Change, Past Behavior, and Grandfathering, 37 J. LEGAL STUD. 37, 71, 73-75 (2008) (illustrating how grandfather status allows for noncompliance with the regulation). 
not. ${ }^{220}$ This has the ironic effect of slowing capital turnover because abandoning the capital also means abandoning the valuable asset (grandfather status), thereby delaying the achievement of air quality benefits. ${ }^{221}$

A number of arguments have been offered in favor of transition relief, but none are as general as the arguments against it. Expensive, iterative technologically-based pollution control mandates may warrant some transition relief. ${ }^{222}$ But the context in which transition relief is discussed is not often of such a clumsy command-and-control sort. ${ }^{223}$ It could also be that awarding transition relief is a second-best outcome, inferior to a policy change unaccompanied by transition relief, but better than the status quo. ${ }^{224}$ But government's inability to ascertain the private costs and call a bluff is an invitation to rent-seeking that may swamp any potential private palliative benefits. ${ }^{225}$ Finally, it has been argued that regulatory bodies, not capital investors, are in a better position to anticipate new regulation. ${ }^{226}$ But to the extent that new regulation is meant to address changing market conditions and emergent harms of some product or process, it would seem to be capital investors, not regulatory bodies, that are likely to have superior information. ${ }^{227}$ It is their capital, after all, and in the first instance it would be capital investors undertaking the due diligence of vetting the soundness of their

220. See Robertson, supra note 81, at 160-61, 167-69.

221. See, e.g., Hsu, supra note 81, at 10,096 (discussing grandfathering's drag on capital turnover); John A. List, Daniel L. Millimet \& W. Warren McHone, The Unintended Disincentive in the Clean Air Act, 4 ADVANCEs ECON. ANAlYsis \& POL'Y, no. 2, 2004, at 1, 13-14 (finding "deleterious effects on plant-level modification decisions"); Randy A. Nelson, Tom Tietenberg \& Michael R. Donihue, Differential Environmental Regulation: Effects on Electric Utility Capital Turnover and Emissions, 75 REv. ECON. \& STAT. 368, 369, 371, 373 (1993).

222. See Shavell, supra note 219, at 71-73 (discussing benefits and concerns of grandfathering as transition relief).

223. See Cass R. Sunstein, Administrative Substance, 1991 DUKE L.J. 607, 627, 638 $39,641,645$ (suggesting that command-and-control regulation is responsible in large part for regulatory failure in the United States); Cass R. Sunstein, Congress, Constitutional Moments, and the Cost-Benefit State, 48 STAN. L. REV. 247, 273, 297-300 (1996) (reasoning that command-and-control regulation can often be dysfunctional).

224. See Levmore, supra note 214, at 1665-66 (suggesting that to achieve policy change, a norm must be developed); Jonathan S. Masur \& Jonathan Remy Nash, The Institutional Dynamics of Transition Relief, 85 N.Y.U. L. REV. 391, 400-01 (2010) (explaining under what conditions transition relief may be superior to the status quo).

225. See Levmore, supra note 214, at 1666-68 (sharing a pessimistic view of transition relief).

226. See, e.g., W. Kip Viscusi, The Dangers of Unbounded Commitments to Regulate Risk, in Risks, Costs, AND LIVES SAVED 135, 137, 139 (Robert W. Hahn ed., 1996) (demonstrating why regulatory bodies are better inclined to anticipate changes).

227. Levmore, supra note 214, at 1657, 1659 \& n.5, 1675, 1680. 
investment. For example, there is no reason to believe that the Environmental Protection Agency would have any advantage in anticipating the environmental risks of hydraulic fracturing than the oil and gas companies that engage in it.

But all of these arguments speak to behavior after the formation of capital. The less obvious but possibly greater distortion is the ex ante effect that an expectation of grandfathering has on capital investment decisions. A substantial part of the risk of new capital is the risk of premature obsolescence due to regulatory action, the emergence of superior alternatives, or some other unexpected shock. 228 Absent risk, there is no reason that investors would abstain from supersizing their capital investments. Insuring, even partially, against the risk of obsolescence by regulation biases investors towards larger capital investments. And all other things being equal, larger capital investments will inspire larger efforts to defend them. ${ }^{229}$

It is thus not so much that grandfathering inhibits policy change because it delays compliance with updated standards of behavior (a common complaint from environmentalists); ${ }^{230}$ it is that grandfathering inhibits policy change because it emboldens capital investors. Armed with the knowledge that legislatures and agencies will only reluctantly impose new costs, capital investors will, from a societal point of view, overinvest. Moreover, the more expensive the capital, the more reluctant lawmakers will be to regulate it. ${ }^{231}$

So common is the provision of at least some transition relief $^{232}$ that regulatory targets cannot help but notice and feel at

228. See David Gabel, Divestiture, Spin-Offs, and Technological Change in the Telecommunications Industry-A Property Rights Analysis, 3 HARV. J.L. \& TECH. 75, 9596 (1990) (discussing premature obsolescence in the telecommunications industry).

229. See supra note 96 and accompanying text (discussing the rationale of investing, absent risk).

230. See, e.g., NRDC: Regulating Obesogens, ONEARTH (June 27, 2011), http://www.onearth.org/article/nrdc-regulating-obesogens ("When TSCA was first passed, over 60,000 chemicals were 'grandfathered' in, with no requirement for toxicity information to continue their production.... While rates of diseases linked to chemical exposures continue to rise, the federal system that is supposed to be protecting us is unable to do the job and millions of people are at risk."); see also Natural Res. Def. Council v. Thomas, 838 F.2d 1224, 1243 (D.C. Cir. 1988) ("NRDC attacks several elements of the grandfathering as too generous ....").

231. See Huber, supra note 209, at 127 (describing how "direct and indirect compliance costs associated with regulatory objectives affect their structure and implementation").

232. See Damon et al., supra note 215, at 4-5 (commenting on how grandfather clauses serve as exemptions from regulatory requirements and may or may not be limited to a certain period of time). 
least partially insured against changes in legal rules that might jeopardize their capital. ${ }^{233}$ The provision of transition relief has been elevated to almost norm status. ${ }^{234}$ Capital investors have come to expect a right to extract some profits out of their capital, regardless of its inherent usefulness, and regardless of the social harms it will impose, foreseeable or not. Transition relief, based on a misguided intuition, has made the obsolescence of capital everybody's problem. Everybody, that is, except the owners of obsolescent capital.

\section{E. Regulatory Takings Jurisprudence}

If there were a legal development that would exemplify the misguided bias in favor of capital, it would be the rise in regulatory takings jurisprudence. For approximately the last thirty-five years, the Supreme Court has been extremely interested in scrutinizing land use regulations to see if they are so onerous as to constitute a regulatory taking of property triggering a Fifth Amendment requirement of compensation. ${ }^{235}$ The effects of this doctrinal lurch toward property rights protection are not obvious. But more than any other legal or policy phenomenon, it reveals the one-sidedness with which laws and legal institutions (most prominently the Supreme Court) have come to view capital.

Justice Brennan's three-factor analysis in Penn Central Transportation Co. v. New York City, ${ }^{236}$ still the default test for what constitutes a regulatory taking requiring the payment of compensation, ${ }^{237}$ prominently includes consideration of "the extent to which the regulation has interfered with distinct

233. See Nash \& Revesz, supra note 209, at 1726 ("[W]hen the government enacts a new legal regime with transition relief, it sends a signal to society at large that, in general, changes in legal standards will not govern existing actors.").

234. See Huber, supra note 209, at 98, 112 ("[F]ull grandfathering is the norm in land use regulation."); Kyle D. Logue, Legal Transitions, Rational Expectations, and Legal Progress, 13 J. CONTEMP. LEGAL Issues 211, 215 (2003) (noting the "legislative norm of applying legislative changes nominally prospectively").

235. See Joseph L. Sax, Land Use Regulation: Time to Think About Fairness, 50 Nat. RESOURCES J. 455, 457 (2010) ("[D]uring the FDR era, the Court became more sympathetic to regulation, only to shift again starting around 1980. In recent decades, the more conservative majority on the Supreme Court has shown that the Court is, again, quite sympathetic to the constitutional claims of property owners.”).

236. Penn Cent. Transp. Co. v. New York City, 438 U.S. 104, 124 (1978). The three factors are: the character of the government action, the economic impact upon the claimant, and the interference with investment-backed expectations. Id.

237. Lingle v. Chevron U.S.A. Inc., 544 U.S. 528, 538 (2005) ("[R]egulatory takings challenges are governed by the standards set forth in [Penn Central]."); see also Koontz v. St. Johns River Water Mgmt. Dist., 133 S. Ct. 2586, 2604 (2013) (Kagan, J., dissenting). 
investment-backed expectations."238 Although the jurisprudence and the literature do not explicitly say so, investment-backed expectation interests are what judges think are the interests in a stream of benefits stemming from the exploitation of capital. In the numerous regulatory takings cases that followed Penn Central, it is obvious the extent to which courts have paid careful attention to what owners of capital expect. ${ }^{239}$ It is less obvious that courts seem to have lost sight of the social welfare of regulation attacked by regulatory takings litigation.

In Lucas v. South Carolina Coastal Council, perhaps the most prominent beachhead for property rights advocates, the Court squarely focused itself on the impacts on the petitioning landowner, finding that a South Carolina statute, in blocking development of a residential lot on a barrier island otherwise crowded with houses, effectively deprived a land developer of "economically viable use of the land."240 Justice Scalia's majority opinion stated that,

[A]t the time Lucas acquired these parcels, he was not legally obliged to obtain a permit from the Council in advance of any development activity. His intention with respect to the lots was to do what the owners of the immediately adjacent parcels had already done: erect single-family residences. He commissioned architectural drawings for this purpose. ${ }^{241}$

Quite explicitly, Justice Scalia's opinion, as do the vast majority of regulatory takings cases, places the regulatory takings focus on the effects of regulation on the landowner. ${ }^{242}$ Very little is said anymore about the common law police power that has served as the general regulatory authority for state and local governments for decades. ${ }^{243}$

238. Penn Cent. Transp. Co., 438 U.S. at 124.

239. See, e.g., Tahoe-Sierra Pres. Council, Inc. v. Tahoe Reg'l Planning Comm'n, 535 U.S. 302, 352 (2002) (Rehnquist, J., dissenting) (noting the extent to which the duration of a moratorium interferes with the economically beneficial use of the land); Palazzolo v. Rhode Island, 533 U.S. 606, 626-27 (2001) (finding that regulations existing at the time of purchase are not the sole determiner of investment-backed expectations and can be challenged); E. Enters. v. Apfel, 524 U.S. 498, 532 (1998) (holding that a requirement to make retroactive contributions to a fund for coal mine workers suffering from black lung disease frustrated petitioner's investment-backed expectations).

240. Lucas v. S.C. Coastal Council, 505 U.S. 1003, 1006-09, 1016, 1031-32 (1992).

241. Id. at 1008 (emphasis added).

242. See id. at 1008-09, 1027-31 (highlighting how the Beachfront Management Act disturbed the petitioner's property rights); see also Tahoe-Sierra Pres. Council, Inc., 535 U.S. at 306, 320-24; Penn Cent. Transp. Co., 438 U.S. at 124-25, 136-38.

243. D. Benjamin Barros, The Police Power and the Takings Clause, 58 U. Miami L. REV. 471, 472 (2004) (“The term 'police power'... has been ignored in contemporary takings jurisprudence.”). 
In Rose Acre Farms, Inc. v. United States, one of the largest egg producers in the United States challenged an emergency order by the U.S. Department of Agriculture to slaughter all of the chickens in three of Rose Acre's large chicken egg farms and to clean and sanitize the hen houses, following a series of salmonella outbreaks that were all traced to the three farms. ${ }^{244}$ Rose Acre was still allowed to sell the eggs in liquid form. ${ }^{245}$ Rose Acre still sued, claiming that its diminished profits constituted a regulatory taking. ${ }^{246}$ Astonishingly, the Court of Federal Claims agreed, ruling that the emergency health order did in fact unconstitutionally take Rose Acre's property, awarding Rose Acre over $\$ 6$ million in damages. ${ }^{247}$ Applying the Penn Central test, the court held that the order interfered with Rose Acre's investment-backed expectations, ${ }^{248}$ that the economic impact upon Rose Acre was severe, ${ }^{249}$ and that the character of the government action impermissibly favored the government. ${ }^{250} \mathrm{On}$ appeal, the Court of Appeals for the Federal Circuit reversed, but left intact the lower court's application of the investment-backed expectations part of the test. ${ }^{251}$ Even as the court cautiously upheld an emergency public health measure to prevent the recurrence of a harm traceable to the petitioner's farms that had already sickened hundreds of people, ${ }^{252}$ the court let stand the hopelessly one-sided part of the lower court's opinion regarding the effect on petitioner's capital. ${ }^{253}$

One could argue (many have) that property law in particular has gotten carried away with thinking about rights and neglecting correlative duties. ${ }^{254}$ The Supreme Court has certainly

\footnotetext{
244. Rose Acre Farms, Inc. v. United States, 55 Fed. Cl. 643, 646-52 (2003), rev'd, 559 F.3d 1260 (Fed. Cir. 2009), cert. denied, 559 U.S. 935 (2010).

245. Id. at $647 \&$ n. $1,648$.

246. Id. at 653 .

247. Id. at 670 .

248. Id. at 659 .

249. Id. at 658 .

250. Id. at 659-60.

251. Rose Acre Farms, Inc. v. United States, 559 F.3d 1260, 1265-66, 1275-76, 1283-84 (Fed. Cir. 2009).

252. Id. at 1262-64; Brief for the United States in Opposition at 2, Rose Acre Farms, Inc. v. United States, 559 U.S. 935 (2010) (No. 09-342) (reporting 3,300 cases of salmonella during a 1986 outbreak).

253. Rose Acre Farms, Inc., 559 F.3d at 1265-66, 1283.

254. See Joseph William Singer, The Ownership Society and the Takings of Property: Castles, Investments, and Just Obligations, 30 HARV. EnVTL. L. REV. 309, 313-14 (2006) (suggesting an alternative model of property that "starts from the idea that owners have obligations as well as rights"); Laura S. Underkuffler, Tahoe's Requiem: The Death of the Scalian View of Property and Justice, 21 Const. Comment. 727, 729, 731-32, 752 (2004) (discussing how "property claims are so often ... unavoidably reciprocal in character" and
} 
done its part to tilt the inquiry in that direction. When the Court has addressed the harm-prevention goals of a land use restriction, it has scrutinized the restrictions and their effectiveness, taking a skeptical view of the assertions of the land use regulatory agencies. ${ }^{255}$ It is striking that regulatory takings law so consciously focuses on the welfare of capital, and not social welfare. Courts have been willing to expand the regulatory takings inquiry into a number of areas beyond land use regulation, including water, ${ }^{256}$ offshore oil leasing, ${ }^{257}$ governmental contractual rights, ${ }^{258}$ and intellectual property. ${ }^{259}$ Electric utilities, facing losses due to new competition arising from deregulation ${ }^{260}$ have even raised regulatory takings claims from de-regulation. ${ }^{261}$ At bottom, regulatory takings law has sought to protect the expectation interests of owners of capital. ${ }^{262}$ This deference to capital owners on the one hand, and skepticism towards the regulator and the social harm on the other, is analogous to the one-sidedness with which we view the benefits and the costs of capital. The law, as we do, only seems to

cause courts to arbitrarily balance "reciprocal evils[ done by reciprocal actors" (internal quotation marks omitted)).

255. In Lucas, Justice Scalia, critical of Justice Blackmun's reliance on the common law police power to permit harm-preventing land use restrictions, writes that

In Justice Blackmun's view, even with respect to regulations that deprive an owner of all developmental or economically beneficial land uses, the test for required compensation is whether the legislature has recited a harm-preventing justification for its action. Since such a justification can be formulated in practically every case, this amounts to a test of whether the legislature has a stupid staff.

Lucas v. S.C. Coastal Council, 505 U.S. 1003, 1025 n.12 (1992) (emphasis added) (citation omitted).

256. Klamath Irrigation Dist. v. United States, 635 F.3d 505, 508-09, 519, 521-22 (Fed. Cir. 2011) (holding that a reduction in a water allocation under a state statute could be a regulatory taking if the allocation was reduced to fulfill trust obligations to Native Americans and to comply with the Endangered Species Act); Tulare Lake Basin Water Storage Dist. v. United States, 49 Fed. Cl. 313, 313-14, 319 (2001) (holding that reducing water deliveries to comply with the Endangered Species Act was a physical taking).

257. Union Oil Co. of Cal. v. Morton, 512 F.2d 743, 746, 751 (9th Cir. 1975) (holding that the suspension of offshore oil drilling operations after a 1969 oil spill off the southern California coast, pending an environmental review, was a taking).

258. Stockton E. Water Dist. v. United States, 583 F.3d 1344, 1369 (Fed. Cir. 2009) (holding that a water contract right-holder could assert a regulatory takings claim for breach).

259. Philip Morris, Inc. v. Reilly, 312 F.3d 24, 45-46 (1st Cir. 2002) (holding that intellectual property rights can be rights that can be the subject of a regulatory taking).

260. See supra Part IV.C (discussing the financial effect of deregulation on incumbent electricity generation firms).

261. Susan Rose-Ackerman \& Jim Rossi, Disentangling Deregulatory Takings, 86 VA. L. REV. 1435, 1457 (2000) (explaining that utilities companies have made takings claims due to so-called "stranded costs" resulting from deregulation).

262. See supra note 239 and accompanying text. 
appreciate the benefits of capital formation, and not so much the costs.

All that said, a consensus seems to exist that the changes in regulatory takings law have been modest. ${ }^{263}$ Regulatory takings jurisprudence over the last thirty years has not remade the legal landscape for land use regulation or for regulation generally. ${ }^{264}$ Regulatory takings law is not exhibit A for this Article's thesis that capital-friendly law has created an overcapitalized economy. Rather, what the last three decades of regulatory takings law seem to show is how legal thinking reflects a desire to protect capital to the detriment of less tangible, more diffuse but potentially much more important social, economic, environmental, and public health interests. Moreover, Justices Scalia, Thomas, Roberts, and Alito, the four justices most inclined to uphold private property rights against governmental interference, may not be done. ${ }^{265}$ Regulatory takings jurisprudence may still yet solidify a legal bias for entrenching capital.

\section{F. The Politics of Human and Social Capital}

All of these laws and regulations confer some preferential, or at least special status on physical capital. But what about social and human capital? It is less obvious, but potentially more important, that law, regulations, government policy, and even private firms have inclinations to protect human and social capital. While laws do not explicitly or structurally favor human or social capital the way they privilege physical capital, it is clear that political institutions bias decisions towards preserving human and social capital. ${ }^{266}$ The pervasiveness of grandfathering is one example. Behind the desire to preserve physical capital lies the connected desire to preserve the jobs, know-how, and social networks that derive from operation of physical capital.

\footnotetext{
263. See, e.g., Sax, supra note 235, at 467 (arguing that the Supreme Court's regulatory takings jurisprudence is undeveloped and unhelpful as applied to general issues of unfairness).

264. See id. at 458 (noting that since the 1980s, the Supreme Court "has failed to provide clear guidance in regulatory takings cases").

265. See, e.g., Garrett Power, Property Rights, the "Gang of Four" \& the Fifth Vote: Stop the Beach Renourishment, Inc. v. Florida Department of Environmental Protection (U.S. Supreme Court 2010), 21 WIDENER L.J. 627, 634, 644-45 (2012) (arguing that the four justices inclined to uphold property rights are still casting for a fifth vote to overrule Penn Central).

266. See, e.g., GOLDIN \& KATZ, supra note 56, at 198 (discussing how state laws that governed school districts' fiscal responsibilities played a prominent role in increasing enrollment in schools by providing poorer school districts with grants to build schools and supplement teacher salaries).
} 
Unlike physical capital, human and social capital are most ardently supported in the legislative branch. For communities, businesses, and industries that are heavily dependent upon their human and social capital, and for whom alternative existences seem remote and implausible, reform represents an existential threat to the owners of that capital. Elections in coal mining communities, for example, become single-issue elections, with coal jobs taking center stage. ${ }^{267}$ In the 2012 election cycle, campaigns in coal country states such as Virginia, Kentucky, and Pennsylvania focused heavily on coal, drawing a number of Democrats into the coal camp. ${ }^{268}$ In West Virginia, where President Obama is viscerally hated for his perceived hostility to coal, ${ }^{269}$ the President was outpolled in several large counties in the state's Democratic primary by a convicted felon, still incarcerated in Texas. ${ }^{270}$

Fortunately for coal-mining communities in West Virginia, they had the luck of being represented by former Senate majority leader Robert Byrd. ${ }^{271}$ In a five-decade-long career in the Senate, Byrd regularly championed coal-mining communities, regularly foiling air pollution regulation efforts:

267. See, e.g., Bruce Schreiner, Grimes Defends Coal, Touts Jobs Plan for Kentucky, MiAMI HERALD (Jan. 16, 2014), available at www.miamiherald.com/2014/01/16/3875793/ grimes-defends-coal-touts-jobs.html ("Coal mining, a major industry in Kentucky, has emerged as a central issue in the Senate race."); Jennifer Yachnin, Republicans Talk Up Coal, Keystone XL as Economic Themes Take Center Stage, GreEnwIRE (Aug. 29, 2012), http://www.eenews.net/greenwire/stories/1059969329/print ("Republican candidate Andy Barr [argued that] [t]his year alone, 2,000 Kentucky miners lost their jobs because of overregulation and Obama's war on coal. For every mining job lost, three additional jobs are threatened." (internal quotation marks omitted)).

268. Roger Alford, Chandler, Barr Spar Over Economy, Jobs, ST. J. (Oct. 30, 2012), available at http://www.state-journal.com/local\%20news/2012/10/30/chandler-barr-sparover-economy-jobs (noting coal's importance to Kentucky candidates in the 2012 U.S. Senate race); Josh Kurtz, 2 Democrats in Close Races Profess Strong Support for Coal in New TV Ads, E\&E NEws PM (Sept. 13, 2012), http://www.eenews.net/eenewspm/ stories/1059969935/print ("In Virginia, former Gov. Tim Kaine (D), who is locked in a tight open-seat race against former Sen. George Allen (R), launched an ad today in which he touts the help his administration gave a coal plant in southwest Virginia when he was governor. . . 'This state-of-the-art coal plant in southwest Virginia, where my wife's from, created 2,500 new jobs,' Kaine says.... Meanwhile, in Pennsylvania's 12th District... Rep. Mark Critz (D) began airing an ad...that blisters the Obama administration for its environmental regulations. 'Seven hundred coal jobs depended on building an air shaft at the Cumberland Mine,' Critz says...' 'b]ut we had to fight President Obama's EPA to get it built."').

269. Manuel Quinones, Appalachia Fights Back Against President's Coal Policies, ENV'T \& ENERGY DAILY (May 10, 2012), http://www.eenews.net/stories/1059964186/print (referencing Obama's low popularity ratings in West Virginia due to his "agenda to tighten pollution controls").

270. Id.

271. Adam Clymer, A Pillar of the Senate, a Champion for His State, N.Y. TIMES, June 29, 2010, at A1. 
Arguments have been made that costs and dislocations caused by the compliance requirements of this legislation pale in comparison to the public health benefits. But what will we really have accomplished if we succeed in removing certain pollutants from the air and at the same time level the economies of whole communities and regions? Is that progress? Is that kind of devastation not even to be considered here? ... When mines are shut down, not only do miners and their families suffer but whole communities also suffer. ${ }^{272}$

What is it about coal mine workers and their communities that make them so invested in a livelihood so fraught with danger and disease? ${ }^{273}$ Granted, culture, identity, and personal pride are at work. But part of the answer must also be that there is embedded but unpriced capital in coal mining. This not only includes the physical equipment for coal mining operations, but also potentially more importantly, a tremendous amount of social and human capital wrapped up in coal mining and its ancillary businesses.

By no means is coal mining special among resource industries. Rural communities in many resource exploitation industries have found political champions that have sought to protect the social fabric around which their economic and social lives are bound. Logging communities found an ally in the late U.S. Senator Slade Gorton:

That preservation law has wreaked incomprehensible havoc on timber families who have had to live with prolonged uncertainty about their futures. All indices of human despair have gone through the roof in these communities: child abuse, spousal abuse, alcohol and substance abuse, divorce, adolescent depression and suicide attempts, bankruptcies, and illness. All of these have been exacerbated by the terrible and unintended consequences of the Endangered Species Act of 1973.274

272. 136 CONG. REC. 796-97 (1990) (statement of Sen. Robert Byrd).

273. Div. of Respiratory Disease Studies, U.S. DeP'T of Health \& Human Servs., Pub. No. 94-120, Work-Related Lung Disease SuRVeillance REPorT 30 tbl.3-1 (1994), available at http://www.cdc.gov/niosh/docs/94-120/pdfs/94-120.pdf (identifying coal mining as occupation on death certificate in sixty-nine percent of pneumoconiosis-related deaths between 1985 and 1990); NAT'L INST. FOR OCCUPATIONAL SAFETY \& HEALTH, U.S. Dep’t of Health \& Human Servs., Pub. No. 201-172, Coal Mine Dust Exposures and Associated Health Outcomes: A Review of Information Published Since 1995, at 19 figs.14-15 (2011), available at http://www.cdc.gov/niosh/docs/2011-172/pdfs/2011172.pdf (showing age-adjusted death rates, years of potential life lost before age sixty-five, and mean years of potential life lost (per million) for decedents age twenty-five years or older in the United States between 1968 and 2006 with coal workers' pneumoconiosis as the underlying cause of death).

274. 138 CONG. REC. 31,856 (1992) (statement of Sen. Slade Gorton). 
And in the environmentally-minded state of Massachusetts, the uniformly Democratic congressional delegation has consistently and vigorously fought fishing limitations set by the National Marine Fisheries Service under the Sustainable Fisheries Act. ${ }^{275}$ Iconic liberal Congressman Barney Frank, who held a ninety-two percent favorability rating from the League of Conservation Voters when he retired in $2012,{ }^{276}$ has often led the charge. In a 2009 letter to National Oceanic and Atmospheric Administration (NOAA) Administrator Jane Lubchenco, Frank urged Dr. Lubchenco that the NOAA "must be willing to act on its own to ensure decisive and immediate action to implement revised regulations necessary to protect fishermen and fishing communities from unnecessary and often devastating financial hardship."277 Several months later, after apparently receiving little mollification from Lubchenco, Frank called for her resignation, putatively over agency misconduct. ${ }^{278}$ Massachusetts Attorney General Martha Coakley, in suing NOAA last year for setting tight fishing limits, complained of a "callous disregard for the well-being of New England fishermen," that will lead to the "extinction of an industry that for more than a century has been a part of the commercial and social fabric of New England."279

What these statements exemplify is a rhetorical focus on jobs, families, and communities. In the vernacular of this Article, they represent human capital and social capital, and in rural, resource-based economies, they represent capital in groups where capital is otherwise scarce. When human and social capital are the only assets belonging to an individual or a group, a threat to that capital sets up a particularly acute public choice problemthe interests of capital owners are extremely and intensely

275. 16 U.S.C. §§ 1801-1884 (2012); Shawn Zeller, Fish Fight: The Massachusetts Congressional Delegation Is Usually in Sync with Environmentalists, but Not on Fishing Limits, CommonWealth (Apr. 12, 2011), http://www.commonwealthmagazine.org/ Departments/Washington-Notebook/2011/Spring/Fish-fight.aspx ("[T]he Massachusetts representatives insist that it's they who are in the right, defending an ancient way of life against rules that they believe will drive small fishermen out of business.").

276. National Environmental Scorecard: Representative Barney Frank (D), LEAGUE OF CONSERVATION VOTERS, http://scorecard.lcv.org/moc/barney-frank (last visited Feb. 11, 2014).

277. Letter from Barney Frank, Rep., U.S. House of Representatives, to Dr. Jane Lubchenco, Adm'r, Nat'l Oceanic and Atmospheric Admin., U.S. Dep't of Commerce (Oct. 26, 2009), available at http://www.savingseafood.org/images/documents/congress/10_26_ 09_lubchenco_frank.pdf.

278. Matt Viser, Frank, Tierney Call on NOAA Chief's Dismissal, Bos. GLOBE (July 8, 2010), http://www.boston.com/news/politics/politicalintelligence/2010/07/frank_calls_on. html.

279. Petition for Judicial Review at 1-2, 6, Massachusetts v. Blank, 1-13-cv-11301 (D. Mass. 2013), available at http://www.mass.gov/ago/docs/press/2013/1-13-cv-11301.pdf. 
concentrated, as opposed to those that would benefit from environmental protection. This dependence on continued exploitation of capital can generate psychological effects that defy objective facts. Desperate owners of threatened capital will zealously reject notions that their practices and their capital have become harmful or anachronistic. ${ }^{280}$

\section{Whither, CAPital? A Refocus on Public Goods}

It is important to emphasize what this Article is not arguing. This Article is not arguing that the formation of capital should never be promoted or subsidized or that capital should never be protected. Public goods, ${ }^{281}$ after all, are often capital goods, and this Article is certainly not arguing that we should abandon direct government provision or funding of national defense, schools, parks, law enforcement, and a judiciary, all of which are capital goods within the working definition set out in this paper. ${ }^{282}$

The conceptual difficulty is that public goods are rarely "pure," in that they are perfectly nonexcludable and perfectly nonrivalrous. ${ }^{283}$ The question for government provision or funding of a given project then, is how "pure" of a public good is the project? There are certainly capital goods that are not purely public goods but may be quasi-public goods, and sufficiently possess public good characteristics as to warrant subsidization. Network goods, such as railroad lines, roads and highways, and ports all have at least some degree of public funding, direct or indirect. ${ }^{284}$

280. See, e.g., Kimberly Morrison, Fishing Industry Fights Red Snapper Regulations, JACKSONVILLE BUS. J., http://www.bizjournals.com/jacksonville/stories/2009/06/01/ story5.html (last updated May 28, 2009) (discussing a situation where fishermen strongly opposed federal regulation of red snapper fishing even though an assessment showed the snapper were being overfished at "nine times the sustainable level").

281. Public goods are nonexcludable (meaning that once they are provided, people cannot be excluded from enjoying them), and nonrivalous (meaning that consumption by one individual does not detract from consumption by another). See ROBERT CAMERON MITCHELL \& Richard T. Carson, Using Surveys to Value Public Goods: The Contingent Valuation METHOD 1 n.1 (1989); RichaRd CORNES \& TODD SANDleR, THE THEORY OF EXTERnALITIES, PUBliC GoOds, AND CluB Goods 8-9 (2d ed. 1996).

282. See supra Part II (defining capital as "a long-lived asset that generates a stream of benefits" (emphasis omitted)).

283. See Mitchell \& CARSON, supra note 281, at 1 n.1 ("Pure public goods are characterized by the conditions of non-excludability of and non-rivalry congestion between individuals who wish to use the good .... In the real world, few public goods meet these strict conditions ....").

284. See, e.g., House Comm. ON Transp. \& InFrastructure, Improving the Nation's Freight Transportation System: Findings and Recommendations of the Special Panel on 21st Century Freight Transportation 15, 31, 3753 (2013) (discussing federal funding programs for highways, harbors, airports, and railroads). 
But one reason that legal institutions have gotten into the bad habit of overpromoting capital is that some capital projects have looked enough like public goods to warrant subsidization. Certain capital projects hold the promise of conferring new positive externalities so as to apparently justify government funding or some other legal mechanism to promote its development. So how can meritorious public good-like projects be distinguished from the ordinary capital projects which require no public support and are simply part of the overcapitalization problem?

One type of misguided motivation for promoting capital is an apparent desire for low commodity prices. Driving energy prices down and keeping them low appears to have been a central part of American industrial policy. ${ }^{285}$ An original justification for subsidies was to stimulate capital investment in the oil and gas industries, once considered undercapitalized and immature. ${ }^{286}$ Favorable tax rules incentivized exploration and production by reducing capital costs and uncertainty, ${ }^{287}$ an effort that has been spectacularly successful. ${ }^{288}$ Capital investment in these sectors is considerably higher than private investment alone would have achieved. ${ }^{289}$ But well past the point at which the oil and gas industries in the United States could be considered immature, and past the point at which firms were unable to diversify risks of failure, the subsidies persisted. ${ }^{290}$ Once the old justifications

285. See Mona Hymel, The United States' Experience with Energy-Based Tax Incentives: The Evidence Supporting Tax Incentives for Renewable Energy, 38 LOY. U. CHI. L.J. 43, 67 (2006); see also Reforming Energy Subsidies: Summary Note, IMF, http://www.imf.org/external/np/fad/subsidies/pdf/note.pdf (last visited Feb. 6, 2014) (explaining how subsidies are meant to maintain low prices for consumers); Yuki Noguchi, Solyndra Highlights Long History of Energy Subsidies, NPR (Nov. 16, 2011), http://www.npr.org/2011/11/16/142364037/solyndra-highlights-long-history-of-energy-

subsidies (describing the long history of subsidies, beginning in 1918, for the American oil and gas industry).

286. Hymel, supra note 285, at 47.

287. Id.

288. See id. at 64-65 ("The federal government's huge investment in the petroleum industry ... influenced how quickly and dramatically the United States developed into a fossil fuel-driven society."); Mead, supra note 110, at 352 ("[T] ax subsidies led to increased capital flows into exploration... and production was stimulated.... [I]ncreased production led to lower oil prices and established the historic U.S. low-price policy for energy.").

289. See Cox \& Wright, supra note 110, at 188-89 (demonstrating how special tax provisions have increased investment in petroleum reserves); Mead, supra note 110, at 352 ("[T] ax subsidies led to increased capital flows into exploration."); supra text accompanying notes 132-33 (discussing the staggering oil and gas subsidies that spurred this capital investment).

290. Hymel, supra note 285, at 47-48 (stating that the tax subsidies persisted even when it was clear that the nation's increasing demand for oil showed no signs of slowing). 
became implausible, new justifications emerged: (i) that national security demanded an expansion of supply to reduce dependence upon unstable foreign regimes, ${ }^{291}$ and (ii) the maintenance of low consumer prices. ${ }^{292}$ Such ex post rationalization of continued subsidies is a hallmark of an overcapitalized industry addicted to government support.

Promoting the formation of capital to maintain low commodity prices is mistaken thinking because low commodity prices are not a public good. ${ }^{293}$ It is true that low energy prices spur all kinds of economic activity that might not have occurred without them. ${ }^{294}$ In that sense, capital producing low energy prices produces substantial positive externalities. But as the last half-century of energy development has demonstrated, subsidizing fossil fuels is not the only way to produce low energy prices. But because of huge amounts of entrenched capital in the fossil fuel industries, change has been slow coming. ${ }^{295}$

This pattern of initial government subsidization, followed by large capital inflows into a targeted sector, followed by a stubborn resistance to subsidy reform, repeats itself in a number of resource sectors. Agricultural subsidies in the United States have not only distorted markets, but they also contributed to the capital intensification of agriculture. ${ }^{296}$ Fisheries subsidies have created a larger fleet of larger fishing boats, exacerbating an overcapitalization problem and creating a persistent overfishing problem. ${ }^{297}$ Unsurprisingly, reform in these and other capital-

\footnotetext{
291. Id. at 68,70 .

292. Id. at $47-48$.

293. See supra note 281 (defining "public goods").

294. See, e.g., Hymel, supra note 285, at 67 (illustrating how low energy prices often encourage petroleum consumption rather than conservation); David M. Smolin, The Paradox of the Future in Contemporary Energy Policy: A Human Rights Analysis, 40 CuMB. L. REv. 135, 172 (2009) ("Conventional energy policy seeks to facilitate an adequate supply of energy at a low price in order to facilitate economic activity and growth.”).

295. Hymel, supra note 285, at 67 (discussing how increased profitability in the petroleum industry "increased investments in petroleum exploration" but "inhibited the development of alternatives to fossil fuels"); see also supra Part III.A.

296. SuZANne IUdicello, Michael Weber \& Robert Wieland, Fish, Markets, AND Fishermen: The ECONOMICS OF OvERFISHING 60 (1999) ("[T] policies is that they distort the way markets operate...."); William S. Eubanks II, A Rotten System: Subsidizing Environmental Degradation and Poor Public Health with Our Nation's Tax Dollars, 28 STAN. ENVTL. L.J. 213, 214-15 (2009) (arguing that the United States Farm Bill "encourages overproduction, trade distortion, and depression of world market prices").

297. IUDICELLO, WEBER \& WIELAND, supra note 296, at 60-63 (explaining how subsidies have led to overexploitation of marine life by encouraging the use of "technology that increases the capacity to exploit natural resources" and creating "oversized fishing fleets and ... overfishing").
} 
heavy sectors has been virtually impossible. ${ }^{298}$ And worthy of note, it has not necessarily been the absolute size of the costs of government support that is of such great importance to the capital-owning resource users; it is the relative importance of their capital in their otherwise capital-poor environments that motivate them to strongly resist reform. ${ }^{299}$

Public policy toward the formation and protection of capital must clearly be refocused. The allure of low commodity prices, resource sector development, and economic development generally has detracted from what should be the focus of government provision and subsidization: public goods. Conceding that distinguishing public goods or quasi-public goods from ordinary capital projects is difficult, I propose one guiding principle: public goods or quasi-public goods are often network goods. Roads and highways, railroad lines, telephone and telecommunications networks, fiber optic cables, and the Internet itself are all network goods. ${ }^{300}$ These goods have (or have had) the potential to dramatically expand commerce, by providing new means of transportation or communication. Network goods do not merely confer positive consumption externalities ${ }^{301}$ or merely embody complementarity with other goods, ${ }^{302}$ but rather provide either electronic or physical linkages among users or among nodes. ${ }^{303}$ Networks embody some public good aspects in that there are large economies of scale involved, with marginal costs

298. Id. at 65, 70 ("Despite their lack of economic soundness and the demonstrable damage they have done to both fish populations and fishing fleets, subsidies ... persist in the face of criticism.... Efforts to remove subsidies face tremendous political opposition ...."); Michael Pollan, You Are What You Grow, N.Y. Times MAG. (Apr. 22, 2007), available at http://www.nytimes.com/2007/04/22/magazine/22wwlnlede.t.html? pagewanted=all (noting that the current farm subsidy structure has been in place for the last few decades).

299. See supra Part III.B (discussing how capital owners will fight vigorously to protect their hoped-for stream of benefits generated by their human or social capital).

300. For a general description of network "industries," see LAWRENCE J. WHITE, U.S. Public Policy TOWARD Network Industries 5-8 (1999), which describes network industries and distinguishes between one-way and two-way networks, and Shmuel S. Oren \& Stephen A. Smith, Critical Mass and Tariff Structure in Electronic Communications Markets, 12 BELL. J. ECON. 467, 467 (1981), which explains why a network can be considered a "public good."

301. A positive consumption externality is the positive effect of additional consumption by others. See, e.g., Michael L. Katz \& Carl Shapiro, Network Externalities, Competition and Compatibility, 75 AM. ECON. REv. 424, 424 (1985).

302. See WHITE, supra note 300, at 2 (commenting on how "network industry" has "become an expansive, all-inclusive phrase that appears to embrace almost any composite good or service embodying complementary components").

303. Id. (suggesting that in some network industries "there are physical or electronic linkages that create networks"). 
declining steeply with consumption. ${ }^{304}$ Networks are also characterized by at least some degree of nonexcludability or some degree of nonrivalrous consumption. ${ }^{305}$

I emphasize the support of network capital because the connectivity created by networks has the potential to deliver the kind of outsized economic benefits delivered by public goods. The opening up of channels of commerce is perhaps the most fundamental economic function of government. 306 Commercefacilitating networks produce the greatest gains when they lower the transaction costs of meeting and exchanging for persons and entities that otherwise have no previous relationship and are in that sense "unorganized." 307 Such a network must hold out the promise of a fruitful exchange, so access and cost are important. Carol Rose, in writing about the role of navigable waterways in promoting commerce, has characterized such spaces as "inherently public" space, ${ }^{308}$ where the costs of utilization are so low that spontaneous, unorganized commerce can take place. Water-based commerce represents a vital stage in the economic development of almost every modern society. ${ }^{309}$ Similarly, the provision of railroads, roads, highways, and the Internet each delivered, in their own time, a crucial connectivity that opened up entirely new sets of possible transactions, and produced previously unimaginable gains from trading. ${ }^{310}$

304. Id. at 8-9; Michael Hsu, An Introduction to the Pricing of Electric Power Transmission, 6 UTIL. POL'Y 257, 257-58 (1997).

305. See Mitchell \& CARSON, supra note 281, at $1 \mathrm{n}$.1. (stating that few public goods fully exemplify the nonexcludability and nonrivalry traits); see, e.g., Brett Frischmann, Privatization and Commercialization of the Internet Infrastructure: Rethinking Market Intervention into Government and Government Intervention into the Market, COLUM. SCI. \& TECH. L. REV., June 2001, at 1, 25-26 (noting that the Internet is nonexcludable and only "sometimes rivalrous").

306. See, e.g., Carol Rose, The Comedy of the Commons: Custom, Commerce, and Inherently Public Property, 53 U. CHI. L. REV. 711, 770 (1986) (discussing "[t]he great commerce clause" and positing that "[t]hrough ever-expanding commerce, the nation becomes ever-wealthier").

307. Id. at 720-21, 765 (commenting on the role of navigable waterways in promoting commerce).

308. Id. at 720-21, 772-73 (characterizing "inherently public property" as "fully controlled by neither government nor private agents").

309. See, e.g., HOUSE COMM. ON TRANSP. \& InFRASTRUCTURE, supra note 284, at 27 ("Moving people and goods over water is arguably the oldest form of transportation in human history. For millennia, civilizations have depended upon ships to move goods to support nations and economies.").

310. Id. at 11-13 (illustrating, for example, how a simple tee-shirt ordered in the United States from overseas moves by truck and ocean vessel or aircraft before arriving in the United States and being sent to the customer by freight or truck). Just as an example, agricultural advances occurred with the expansion of crop varieties, which was made possible by the expansion of the railroad network. GOLDIN \& KATZ, supra note 56, at 265. 
In the energy realm, there is one capital network worth promoting: electricity transmission lines. The traditional electricity paradigm of base-load power plants belonging to a vertically integrated utility, operating as a regulated monopoly with exclusive access to a customer base, is gradually giving way to a deregulated, decentralized paradigm which would, in theory, include a variety of ways for electricity supply to meet demand. ${ }^{311}$ A deregulated and decentralized electricity supply system would include the entry of new energy sources, demand reduction and conservation measures, and pricing schemes aimed at smoothing consumption patterns, thereby reducing daily peak demands. ${ }^{312}$ Crucial in a shift to a new electricity paradigm is the opening up of electricity markets to new entrants, and the introduction of competition for electricity consumers. Indeed, publicly-funded networks such as roads, highways, and rail lines have benefited fossil fuel industries enormously by lowering the costs of transporting fossil fuels, a benefit that continues to afford fossil fuels an advantage over renewable energy sources. ${ }^{313}$ To do this, a network of transmission lines that was designed to deliver base-load power to captive consumers must be technologically and economically transformed. ${ }^{314}$ Care must be taken to ensure that network goods are instruments of competition, ${ }^{315}$ as they would if transmission lines reduce the cost of delivering electricity and make possible a greater variety of electricity generation sources, such as wind energy. ${ }^{316}$ Among energy

311. Cearley \& Cole, supra note 192, at 170 .

312. See, e.g., id. at 170, 175-76; Alexandra B. Klass \& Elizabeth J. Wilson, Interstate Transmission Challenges for Renewable Energy: A Federalism Mismatch, 65 VAND. L. REV. 1801, 1811 (2012) (discussing the challenges of wind power).

313. Alexandra B. Klass, Tax Benefits, Property Rights, and Mandates: Considering the Future of Government Support for Renewable Energy 28 (Univ. Minn. Law Sch., Research Paper No. 13-11, Feb. 22, 2013), available at http://ssrn.com/abstract=222298 (explaining how the fossil fuel industry has access to a complex level of infrastructure, such as pipelines, that is not available to other forms of energy like solar or wind energy).

314. See, e.g., Klass \& Wilson, supra note 312, at 1811-12 (explaining why an expansion of the transmission grid will be critical in order to increase the utilization of wind resources). For a review of the complicated issues surrounding a revamping of the electric grid, see PJM, A Survey of Transmission Cost Allocation Issues, Methods, AND PRACTICES 3 (2010), available at http://ftp.pjm.com/ /media/documents/reports/ 20100310-transmission-allocation-cost-web.ashx.

315. Severin Borenstein, James Bushnell \& Steven Stoft, The Competitive Effects of Transmission Capacity in a Deregulated Electricity Industry, 31 RAND J. ECON. 294, 29598 (2000).

316. Wind energy is generally abundant where people are not, such that the most important barrier to entry for wind energy producers is access to electricity customers through the transmission grid. See, e.g., U.S. DEP'T OF ENERGY, 20\% WIND ENERGY BY 2030: INCREASING WiND ENERGY's CONTRIBUtion to U.S. ElECTRICITY SUPPLY 93-100 
experts, energy stakeholders, and even among partisan politicians, there is broad agreement that the U.S. electricity transmission network dramatically needs upgrading. ${ }^{317}$

Transmission lines have many public good aspects. Regional transmission organizations, or RTOs, which are charged with operating most of the transmission capacity in the United States, have become regulated utilities. ${ }^{318}$ By requiring broad access to both electricity consumers and suppliers, which the 2005 Energy Policy Act requires of RTOs, ${ }^{319}$ transmission lines are mandated to assume at least one public good characteristic: nonexcludability. Thus, the development of a cost allocation mechanism, another thorny problem for the development of a transmission policy, ${ }^{320}$ becomes necessary in order for RTOs to remain economically viable.

Distinguishing capital projects worth promoting from those not worth promoting is territory ripe for imprecision, to be sure. However, some guidance on capital investments is surely better than the indiscriminate, all-capital-is-good mindset embodied in existing law and policy.

\section{CONCLUSION}

This Article is the beginning of an exploration of the role of physical, human, and social capital in perpetuating inefficient behavior long after it is recognized as obsolete. If capital is acquired for a very specific purpose and cannot be redeployed for

(2008), available at http://www.20percentwind.org/20percent_wind_energy_report_revOct 08.pdf.

317. Energy Security Analysis, Inc., Meeting U.S. Transmission Needs 19 (2005), available at http://www.eei.org/ourissues/ElectricityTransmission/Documents/ meeting_trans_needs.pdf; ERIC HIRST, U.S. TRANSMISSION CAPACITY: PRESENT STATUS AND FUtURE PROSPECTS 25 (2004), available at http://www.gc.doe.gov/sites/ prod/files/oeprod/DocumentsandMedia/transmission_capacity.pdf; U.S. DEP'T OF ENERGY, NATIONAL TRANSMISSION GRID STUDY 5-7 (2002), available at http://certs.lbl.gov/ntgs/main-screen.pdf; Eric J. Lerner, What's Wrong with the Electric Grid?, INDUSTRIAL PHYSICIST, Oct./Nov. 2003, at 8, 8 .

318. See 16 U.S.C. § 796(27) (2012) (defining "RTO" for purposes of regulatory statutes).

319. Energy Policy Act of 2005, Pub. L. 109-58, §§ 1231, 1291, 119 Stat. 594, 955, 984. North America's electricity grid has been devolved to ten "regional transmission organizations," which are regulated by FERC and are mandated to play the regulated role of an electricity transmission network. See, e.g., FED. EnERGy REGULATORY Comm'n, REGIONAL TRANSMiSSION ORGANIZATIONS MAP (2012), http://www.ferc.gov/industries/ electric/indus-act/rto/elec-ovr-rto-map.pdf.

320. Hung-Po Chao \& Stephen Peck, A Market Mechanism for Electric Power Transmission, 10 J. REG. ECON. 25, 26, 31, 39-40 (1996); William W. Hogan, Contract Networks for Electric Power Transmission, 4 J. REG. ECON. 211, 214-15 (1992) (describing the challenges of a cost-benefit analysis when a grid is used by many relatively small market participants). 
another purpose, then any shift in production methods could effectively "strand" that capital and render it worthless. Especially for mass-produced goods, such as electricity, the cost of capital is large relative to the units in which the benefits flow back to the owner of capital. Payback of capital is accomplished over long time horizons, and over broad populations. When production is undertaken with methods that involve high capital costs and a stream of benefits that are small and widespreadand therefore involve a long payback-a stable pricing and regulatory environment becomes extremely important. A small change in the pricing environment amplified over its application to a large number of customers and transactions results in a potentially huge change. In such an environment, owners of capital can be forgiven for being a bit paranoid and obsessive about protecting their capital by protecting their economic and regulatory environment.

This Article argues that legal rules have helped capital owners control their economic and regulatory environment to the detriment of a broader society. Misguided policy and legal preferences have crept into legal rules and have not only promoted the formation of new capital, but they also protected existing capital from regulatory interference. The problem is thus not just that government has become an insurer against obsolescence; it is that these legal rules insuring capital against obsolescence have biased the mix of capital towards obsolescenceprone capital. The result is a self-reinforcing inefficiency that grows over time, exacerbating latent environmental problems and making them harder to address.

This analysis takes public choice theory into new territory. A theory of capital introduces a new variable not previously considered carefully. The prominence of physical, human, and social capital requires explicit treatment of actors at the individual, firm or sub-industry levels, so as to identify incentive structures at a disaggregated scale. This theory of capital is an exposition of exactly what path-dependency means in the context of industry, firm, and individual behavior. A theory of capital is a form of institutional analysis applied to the choice sets facing industries, firms, and individuals that engage in harmful or inefficient behavior. 